WAHIL KOL

\title{
A YUCATEC MAYA AGRICULTURAL CEREMONY
}

\author{
Bruce Love and Eduardo Períza Castillo \\ Universidad del Valle, Guatemala \\ Transcription and Translation of Chants \\ Bruce Love and Eduardo Peraza Castillo
}

\section{Introduction}

In April, 1978, a Maya agricultural ceremony known as Wahil Kol was performed in Becanchen, a town in the State of Yucatán, México. This paper presents a detailed description of that ceremony, and then addresses certain questions. How does this ceremony compare with descriptions of similar ceremonies recorded by various ethnographers during the last 100 years? What are the main elements of the ceremony? Which parts of the ceremony have changed over the last 100 years and which parts have remained unchanged? And finally, how could ethnographers improve on the way these ceremonies have been recorded in the past so as to facilitate better comparative analysis in the future?

\section{Part I Description of the Ceremony}

\section{A. The Setting}

Becanchen is a small Yucatec speaking town of about 900 residents located in the southern tip of the State of Yucatán. It is about 40 kilometers south of Tekax, a relatively large town on the major 
cross-peninsular highway from Mérida to Chetumal. Located in the Puuc Hills, Becanchen is still relatively isolated, lying at the end of a winding highway leading south which was paved only as recently as 1977.

The principal economy of the town is, without a doubt, maize agriculture. Just about every house has its storage shed in which are kept the ears of maize from the previous harvest. Maize is often used to purchase goods at the local stores. Meat for the village is obtained by hunting in the surrounding forest and by the raising of cattle by a few individuals. There are three stores, a church, a newly built cinema and one cantina. Electricity for the town is provided by a somewhat unreliable gasoline powered generator. There is no running water.

There was one men (often written ah men or $h$-men, he who knows) living in Becanchen, Don Ramón Balam Cámara. He was responsible for leading non-Christian agricultural ceremonies. $\mathrm{He}$ also performed curing to some extent. During April, 1978, he was working as a men, that is, performing rituals, about two days out of the week. One day he went to perform in Peto about two hours away by bus. On the other days, he went to work in his milpa or participated in communal work projects as an ordinary citizen.

In April of that year, I witnessed a particular ceremony known as the Wahil Kol, Bread of the Milpa. This day long event is enacted for the benefit of, and at the request of, an individual head of household. In this case, he was a young man, Luis Xool. The ceremony was performed in the yard of his house and he provided all the food necessary for the preparations of the offering and the rather substantial feast that would follow.

The purpose of the ceremony or central theme, was this. Luis Xool made offerings to the deities to obtain their protection over himself and his family. I was told by the men that if a person neglected to make the Wahil Kol periodically, sickness would befall him or his family. In fact, two weeks later, a man who did have sickness in his family held a Wahil Kol. I was told that his neglect of the ceremony had brought about his problems and now he was attempting to remedy the situation. But Luis Xool was prospering and his young family was healthy.

My friend and informant in Becanchen was a storekeeper, Don Eduardo Peraza Castillo. He was also compadre to Don Ramón, the men. Through Don Eduardo, I received permission to participate 
in, photograph and tape record, the Wahil Kol ceremony in the yard of Luis Xool.

\section{B. The Ceremony}

On the day before the ceremony, the men made a pot of balche'. The ingredients he used were as follows: water, cinnamon, anis seeds, honey and bark of the balche' tree. ${ }^{2}$ First a pot was halffilled with water. Then cinnamon was broken up and dropped into the water. Then the anis seeds were added. Honey was then poured

1 Landa (Tozzer 1941:92) described balche" as a "wine of honey and water and a certain root of a tree, which they cultivated for this purpose by which the wine was made strong and stinking".

Brinton (1883:246) simply referred to it as "The fermented liquor of the country, the pitarilla."

Thompson, E. H. (1932:56) described "a liquor made of honey, water and the bark of the balche' tree, fermented and strangely intoxicating."

Tozzer (1907:123-5) described "a fermented drink made from the bark of a tree called baltše (Spanish pitarilla), mixed with wild honey or sugar cane and water... Baltše is milky white, sour to the smell, and at first very disagreable to the taste. It contains a small percent of alcohol, as it is allowed to ferment... sometimes for not more than a single day." Although this is a description of Lacandon Maya making balche', the Maya of Yucatán made balche" "similar in all respects to that made by the Lacandones", except that it was made "several days before rite [was] to occur", and chili was added to the mixture $(1907: 160)$.

Gann (1918:44) described "a drink made of fermented honey in which is soaked the bark of a tree."

Thompson, J. E. S. (1930:104) writes "Balche... is manufactured from fermented honey and the bark of the balche tree of the genus Lonchocarpus. Sometimes bark of the pine is substituted when there is difficulty in obtaining the balche. Strips of the green bark are washed and then left to dry for some time, the longer the better... When required it is bruised all over with a hammer stone or some similar object. In this way the sap is released. It is placed in a jar in which are equal parts of water and fresh honey. The mixture is then left to ferment for from four to six days. At the end of this period it is ready to drink."

Cruz (1947:104) mentions "Balché aromatizado con canela [cinnamon]."

According to Villa Rojas (1945:109-10), instead of balche, the X-cacal Maya used "a simple mixture of water and honey, a wild honey called chol-cab being preferred..."

Redfield and Villa Rojas (1934:38), in Chan Kom, wrote "Four pieces of bark, about a foot long, are pounded with sticks and placed in a jar with two jicaras of water and a cup of honey. It is left three days and then tested. If it is not good, more honey is added and it is allowed to stand till it comes out yellow, good."

2 The balche' tree is Lonchocarpus violaceus acoording to the Diccionario Maya Cordemex (1980:34), and Lonchocarpus yucatanensis according to Roys (1965:115). 
in, almost filling the pot. The mixture was then stirred with a piece of balche' bark and three pieces of the bark were put in the mixture. The mixture was brought to a boil, then covered and allowed to cool. I was informed that fermentation then began. It was allowed to sit until used in the ceremony.

As I began observing at 7:00 a.m. on the day of the ceremony, preparations were under way in both the house and the yard of Luis Xool. In the back yard (there is no front yard as the front door of the house is right on the street), three men were clearing brush with their short, hooked machetes. In one cleared area, a table $^{3}$ had been set to serve as the mesa. It was set against a young tree so that the thin trunk was on the east side of the table. To this tree, facing the mesa, a crucifix ${ }^{4}$ was tied. On the table was the pot of balche', a gourd cup, a pack of cigarettes and two candles.

From the cleared area around the mesa, a short path led to a larger cleared area where the pit-oven would be.

A domestic turkey was brought to the area of the mesa. The men poured balche' down its throat. Then it was hung from a nearby tree. Its tongue was cut out and as it bled to death, its blood was collected in a small pail which contained about half a cup of salt. Then four chickens were brought over and they were each given balche' (not by the men this time), and their necks were wrung.

3 The table used here was a modern wooden table, the kind found in most houses in that town, manufactured by local carpenters. In another Wahil Kol ceremony performed about 10 days later in another man's yard, the more traditional mesa had been built, using four forked poles for the legs, and other poles bound together to form the flat mesa top.

4 This crucifix belonged to the men. He brought it in the morning and took it with him when he left at the end of the day. It was a wooden cross, about 10 inches high, with a figure of the crucified Christ attached to it.

In another agricultural ceremony, described by Tozzer (1907:161, Pl XXIX, Fig. 2), a wooden cross was placed under the mesa on the east side.

In Gann (1918:43, Fig. 11; 45, Fig. 13) two illustrations of mesas used for the Cha Chaak ceremony both show wooden crosses, but the cardinal direction is not given.

Cruz (1947:103) mentioned "El altar con base de mampostería con tres cruces de madera, la mayor en el centro."

Thompson, J. E. S. $(1930: 115)$ has "At the back of the altar a small rough cross is placed."

Villa Rojas (1945:117, Fig. 9) also shows a cross, but not the direction.

Redfield and Villa Rojas (1934:131) describe the use of the cross "which is always set un in the center of the eastern side of the altar." 
The fowl were then taken to the house area to be prepared for butchering. ${ }^{5}$

For the next couple of hours there were about twenty men and women involved in preparations. I could not observe all the activity that was happening but some of it was as follows:

The fowl were dipped in boiling water, then plucked, then singed over an open fire, then skinned and butchered. The feet of the birds were collected and put in a pile. Their heads were put in a pot and taken to the house area.

As the men continued digging the pit-oven, they made a pile of the stones they removed. Other men brought kindling and large logs to the area. Others brought branches abundant with green leaves.

Women were busy in the house area making dough for the breads and preparing the soup. I assume they were also making the saka at this time.

5 Brinton (1883:246) observed, "On a sort of altar... the native priest places a fowl, and, having thrown on its beak some of fermented liquor of the country... he kills it."

In Gann (1918:45-6, Fig. 13), there is an illustration of the turkey, around whose neck the assistant had placed a wreath of jabin leaves, and poured a little balché down its throat, its legs being held by the assistant. While doing this the priest murmured the following prayer: In kubic ti hahnal cichpan colel, ti San Pedro, San Pablo, San Francisco. Translation: I offer a repast to the beautiful mistress, to San Pedro, San Pablo, San Francisco. The turkey and the other fowls were then killed by having their necks wrung, and the carcasses of all five were removed to the house to be prepared by the women."

Redfield and Villa Rojas (1934:135) observed, "One h-men appoints four persons, whom he calls Chaacs, each one of whom holds a leg or a wing of the fowl while it is ritually killed. The consacration is accomplished by the recitation of a short prayer by the h-men while he puts balche down the victim's beak with a scoop of habin [a leaf]. As the prayer concludes, the assistant (or the four Chaacs) kills the fowl, the hens by wringing their necks, and the turkeys by cutting the tongue or throat and allowing them to bleed to death."

$6 S a k a^{3}$ is a drink of ground, uncooked maize mixed with water. It is drunk cold. While some sources say it was used only ceremonially, others say it was drunk daily as a common breakfast drink. The Motul Dictionary (1929:216) from the early colonial period in Yucatan gives "zacá: atol en lengua mexicana, hecho de agua y maíz; y bébese frío, sin cozer ni calentar, ya entrado el dia; es bevida fresca y sustenta; algunas vezes mésclan cacao en ello."

Thompson, E. H. (1932:62), in connection with the $C h^{\prime} a$ Chaak ceremony, mentioned "The drink sac-ha, made of corn in the milk and wild honey."

Tozzer (1907:161-2) described an agricultural rite performed in Yucatán before burning the milpa called "usăkailkol", saka" of the milpa, but called the offering posol. 
The men took thirteen cigarettes ${ }^{7}$ from the package on the mesa and placed them in a pile on the mesa under the crucifix. He made rings out of vines that would support the gourd cups on the mesa. He made thirteen of these rings and arranged them on the mesa. Frequently the men would go to the various centers of activity to direct and instruct the participants. He also supervised the placement of my tape recorder under the mesa and the fastening of the microphone to the front where he would be standing.

In the house area, some men were heating long thick leaves over an open fire. The leaves were then flattened and stacked to be used later to wrap the breads. Others were pulling long strips from leaves, also to be used in wrapping the breads.

At about $9: 45$, a pot of $s a k a^{\prime}$ was brought to the mesa area. The men put gourd cups in all the rings on the mesa. He poured balche' into the four corner cups and put saka' in the remaining nine (see

Gann (1918:21) described it as "very much like posol, but the corn is not cooked soft, so that the beverage is gritty." During the Ch'a Chaak ceremony that he witnessed, sak $a^{9}$ was placed as offerings in small gourd cups on the altar and in cups that were suspended (1918:45).

In an agricultural ceremony described by Thompson, J. E. S. (1930:115), the owner of the milpa "brings with him five calabashes (Lutš) containing a special posol known as sakqab (white juice) because it contains no lime."

Cruz (1947:103) witnessed a ceremony which had six cups on an altar "conteniendo la bebida refrescante denominada 'zakab', endulzado con miel."

Villa Rojas (1945:55) has, "Zaca, a drink used only in ceremonias, as an offering to the gods and spirits, is a simple preparation, made of maize cooked without lime, then ground, and mixed into water."

Redfield and Villa Rojas (1934:39) have: 'The simplest preparation of maize is zaca. Shelled corn is cooked without lime and ground, and the resulting meal is made into balls. A little is stirred into water. Zaca is not part of secular cookery, but it is the form in which maize is customarily offered to non-Christian gods and spirits."

7 These were factory made cigarettes, bought at the local stores.

Landa (Tozzer 1941:106) described the use of a pipe and what was probably tobacco, by the Maya of Yucatán during their baptismal ceremonies.

Tozzer (1907:142-3, PI. XXI, Fig. 1) observed the Lacandon Maya making offerings of lighted cigars in their renewal rites for braseros, as he called it. "The first tobacco of the year is used in making an offering of cigars. Each is lighted in the new fire, held for a momento in front of the mouth of one of the sacred ollas, and finally leaned up against the head of the incense-burner to which it has been offered. In Yucatan, cigars, rolled in corn husks were placed on the altar in the U Hanli Kol ceremony."

Gann (1918:48) observed at the end of a Ch'a Chaak ceremony the men dividing the sacred breads among the participants "giving each one at the same time a corn-husk cigarette."

Other sources mention the widespread use of tobacco by the Maya, but not in a ceremonial context. 
Fig. 1). A few men came and sat near the mesa while others continued their working.

The men instructed a man, his assistant throughout the day, to light two candles and set them up on the ground beneath the crucifix. $^{8}$ The assistant then lit some incense ${ }^{9}$ which he held in a small open pan, and I was instructed to turn on the tape recorder. As the first chant of the day began, the men in the area removed their hats.

Except for the men himself, there was no apparent attitude of solemnity among the several men casually squatting or sitting in the area of the mesa. Several chatted informally and smiled at my picture-taking while the men chanted over the mesa.

The men chanted, standing before the mesa, facing east. His assistant moved the burning incense all about the legs of the mesa. At one point the men dipped balche' from the pot on the mesa and sprinkled it in the air in four directions. ${ }^{10}$ At the end of the chant

8 Candles on the mesa are described in Gann (1918:45), Thompson, J. E. S. (1930:117), Cruz (1947:103, Fig. 39) and Villa Rojas (1945:114, 116). Gann, Thompson and Villa Rojas point out the use of one or more black candles.

9 I do not know if the incense used here was copal or otherwise. Incense seems to have almost universal use in Maya non-Christian ceremonies. It is depicted in both stone carvings and written codices from pre-Columbian times. Landa mentioned it frequently in connection with native ceremonies.

As for its use specifically in agricultural ceremonies, there are various references. Gann (1918:47) observed in the Ch'a Chaak ceremony, "The assistant then brought up some burning incense (pom) on a piece of plantain bark, which the priest took, and after waving it about for a short time placed it upon the altar."

In the major agricultural ceremony of the X-Cacal Maya, Villa Rojas (1945:114) observed "Pom (copal) was used [on the altar] instead of the usual incense. The pom was tossed on some coals which had been laid on a piece of banana bark."

In the $C h^{\prime} a$ Chaak ceremony described by Redfield and Villa Rojas (1934: 142), "As the h-men prayed, the idzacs [assistants] were sprinkling the altar with balche and adding grains of incense to a small brazier."

10 Much has already been written about the quadripartite nature of the Maya universe and accompanying deities. Vásquez (1976:39) presents the opinion that whether we talk about the Pawatuns, Chaaks, Bakabs, or, in this case, the Yumtsilob, we are dealing with essentially the same thing, i.e., the four directions of the universe, associated colors, winds, rains and agriculture. Tozzer (1941) has many thoroughly researched notes on the subject in the section of Landa's Relación dealing with festivals and rites. See also Thomp^on's (1934:209-242) excellent article, "Sky Bearers, Colors and Directions in Maya and Mexican Religion." 


\section{ARRANGEMENT OF MESA FOR THE CHANTS}

FIRST AND SECOND CHANT
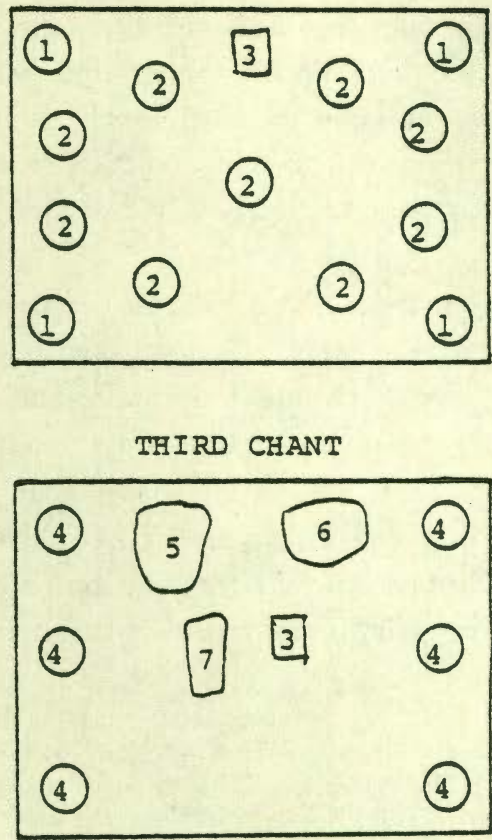

FOURTH CHANT

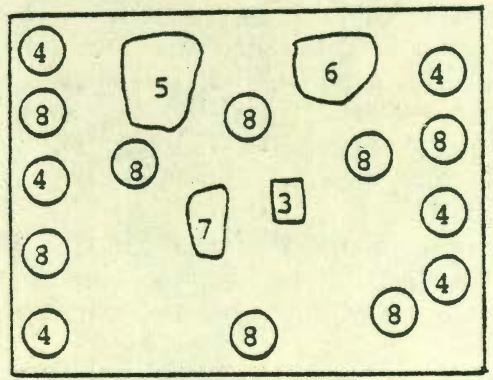

$\begin{array}{ll}1 \text { Balche' } & 5 \text { Bread, wech balls and fowl parts } \\ 2 \text { Saka' } & 6 \text { 13-layer bread } \\ 3 \text { Cigarettes } & 7 \text { Feet of fowl } \\ 4 \text { Soup } & 8 \text { K'Ol }\end{array}$

Figurs 1

Estudios de Cultura Maya. Vol. XV, 1984

Instituto de Investigaciones Filológicas/

Centro de Estudios Mayas, UNAM 
he kneeled and spoke silently with his head bowed. Then he leaned forward and nearly kissed the mesa.

After this chant, the men distributed balche' among the men present and we all drank. The candles remained lit, and soon the second chant began.

At a point during this chant, the men sprinkled saka' in four directions. Always the incense was burning and again at the end there was the kneeling, the silent words, and the kiss.

After this chant, saka' was passed around and drunk. There was no formality here. Men came to drink and left. The cups of saka' and balche' from the mesa were poured back into their respective pots. The men invited me down to the house at this time and the pot of saka' was taken to the house for the women and children to drink.

Outside the house, the soup was still being prepared. Inside, the women were rolling balls of dough and flattening them into thick tortillas (Fig. 2) The tortillas were passed to men who made the breads there in the house.

The breads were made as follows: First, four leaves from the pile of leaves which had been heated and flattened were laid on the floor in an interlocking manner. Onto this the first tortilla was laid. This tortilla was then covered with a spread of sikil. ${ }^{11}$ Then the next tortilla was laid on the first and again covered with the sikil. The bread was thus built up of layers of tortillas and sikil. The first bread had thirteen layers. This was a special bread. They said it was for dios. All the other breads they made that day consisted of twelve layers. ${ }^{12}$ After the last tortilla was in place, one of the

11 Sikil, in this case, refers to a paste made of the ground seeds of the calabaza squash. The ceremonial use of calabaza seeds goes back at least to the 16th century. Landa (Tozzer 1941:142) wrote of the Uayeb festivals in which a heart molded of bread and a heart molded of calabaza seeds were used as offerings.

12 Brinton (1883:246) mentioned "Certain maize cakes of large size and special preparation."

Tozzer (1907:161) described the preparation of bread for the $U$ Hanli Kol ceremony. "...a pile of large and thick tortillas (tutiwa). Between each two of the tortillas there are placed either frijoles, cooked and mashed, or pepita (sikil)...".

Gann (1918:44) has "The masa was taken from the large to the small shed, where the priest and several male members of the family sat around it. After flattening out a small ball of the masa the priest placed it on a square of plantain leaves and poured over it a little sikil (a thin paste made of ground pumpkin seed and water). Then the next man flattened out a piece of masa, which he placed over the sikil, and the process was continued until a 


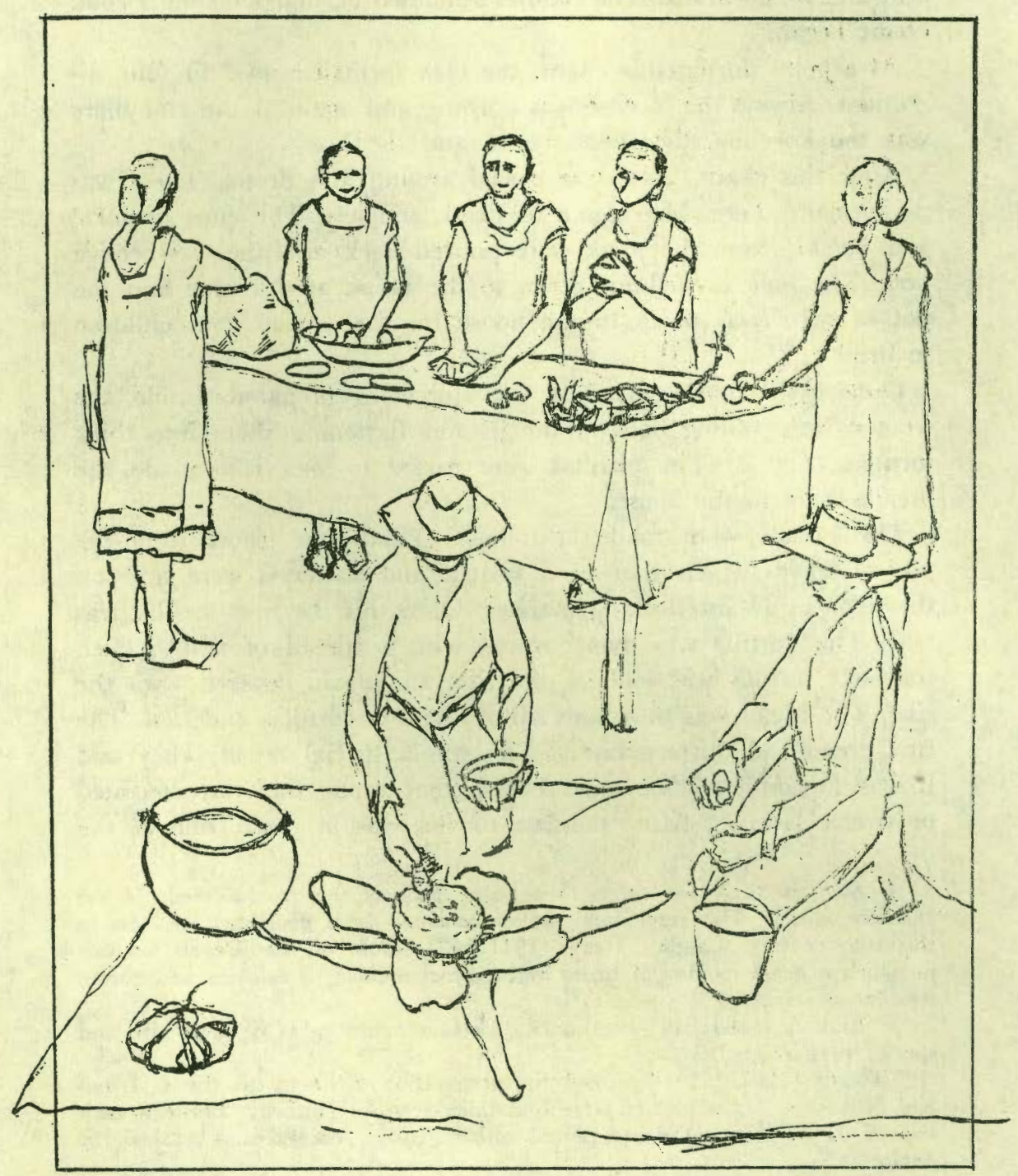

Figure 2. Preparing the sacred bread. Note the wech en the table. 
helpers made four depressions with his finger in the top tortilla, in the form of a square. These were called the eyes of the bread. Into each hole was poured a little balche. Then the holes were plugged with dough and sikil was spread over the top. ${ }^{13}$ The leaves on which the completed bread rested were then wrapped tightly around the bread and tied with the strips already prepared.

The making of the bread lasted about an hour and a half. The women were busy rolling the balls of dough, flattening them into tortillas, and passing them to the men who were making the breads. The pile of wrapped, uncooked breads grew to about three dozen in number.

cake was formed containing 5 to 13 alternating layers of masa and sikil. When sikil is not available, a paste of ground black beans is used."

Thompson, J. E: S. (1930:117) described nine piles of nine tortillas and one of thirteen tortillas used in a primicia ceremony.

Steggerda (1941:57) wrote, "Each is made of 13 layers of large-sized tortillas. Between the layers of some of the loaves cooked beans are placed; others are separated by ground, cooked squash seeds."

Villa Rojas (1945:109) described the preparation of four "great breads" as "A pile of thick tortillas, placed one on top of another, each covered on one side by a paste of zicil... the first is made of thirteen tortillas, and the others of nine, eight, and seven respectively." An indefinite number of other breads were made, each composed of six tortillas.

In the U Hanli Kol ceremony described by Redfield and Villa Rojas (1934:129, 136), four types of breads werc used. Two loaves of "great bread" (the same as described in the previous paragraph), two six-layered breads, one five-layered bread, and six four-layered breads. In addition to sikil being spread between layers, sikil was also pressed into each cornmeal ball before it was flattened.

13 Tozzer (1907:160) has, "On the topmost tortilla of this sandwichlike mass, a cross is made with the pressure of the finger."

Gann (1918:44) wrote, "On top of each cake, as it was completed, the priest traced with his forefinger a cross surrounded with holes; these were first partly filled with balché, which was allowed to soak into the cake, after which they were filled completely with sikil, whereupon the whole cake was carefully tied up..."

Villa Rojas (194:5:109), in describing the "great breads", has, "On the upper surface of each bread a number of depressions equal to the number of tortillas in the entire compound bread are made with the finger and arranged in a circle. In the center of the circle a cross is marked in the same way, and all the depressions are filled with zicil. The dots forming the circle are called 'the eyes of the bread' ( $u$ yich uah)." The breads composed of six tortillas had six "eyes". but no cross.

In Chan Kom, Redfield and Villa Rojas (1934:129) observed, "On the topmost tortilla depressions are made with the finger and filled with zicil. The number of depressions corresponds to the number of tortillas in the pile." On another bread, "cruz-uah", "The topmost tortilla is marked with a cross, filled with zicil." On the six-tortilla bread, "nine depressions in the form of a cross are made with the fingers and filled with zicil." 
Occasionally the men would pass about small quantities of balche' to be drunk.

During this same period a man made what he called a wech, or armadillo, from thirteen balls of dough wrapped in leaves in such a way as to resemble an armadillo, with protruding ears and a long tail of leaves, wrapped with leaf strips ${ }^{14}$ (Fig. 2).

Also during this time, final preparations were being made at the pit-oven. Into the pit, men put kindling, then larger branches of dry wood. Finally, they covered this pile with four to five foot long logs. Onto this were placed all the stones which had been removed when the pit was dug.

At 11:40, the men lit the fire. As the fire burned, it consumed the logs and the heated stones settled into the pit among the glowing coals. Then all the breads and the armadillo were wrapped and ready, they were taken to the pit-oven and placed among the hot stones. The pit was then filled with branches of green leaves. On top of this, were laid some corrugated steel roofing sheets. The soil which had earlier been removed from the pit was then shoveled onto the sheets, sealing the pit, creating the oven.

There followed a period of relaxation as the bread cooked and the soup simmered. Saka' was shared about as people came and went. Most of the men sat in the area of the mesa, chatting and smoking cigarettes, but people came and went freely in the yard and the house.

An hour and a half later when the men decided the bread was baked, activity began again. Men began uncovering the pit-oven. The men removed the vine rings from the mesa, hung them on a nearby tree and began rearranging the mesa. His helper brought three more candles and arranged them with the other two on the ground under the crucifix.

Men removed the exposed breads from the fire with the help of wooden poles. The breads were unwrapped on the spot and piled on a large cloth. The thirteen dough balls from the armadillo were collected in a pail. The breads were carried to the mesa area. The pail of armadillo breads was given to the men.

The special bread with the thirteen layers was placed under the crucifix, a little south of center. The thirteen balls of the armadillo were on a regular bread under the crucifix, a little to the north.

14 The making of an armadillo, or indeed any effigy animal, is not mentioned in any of the references. 
On top of this pile were placed certain turkey parts. The severed feet of the fowl were piled near the center, and the pile of thirteen cigarettes was placed besides them.

Six ceramic bowls were set on the mesa. The men put cooked turkey and chicken meat in the bowls. The large pot of soup was brought over from the house. The men then poured soup into each bowl, over the meat. The bowls were then arranged on the mesa, three on the north side, three on the south.

Several men gathered around the pile of cooked breads on the cloth on the ground and began breaking up the breads with their hands, creating a large pile of bread crumbs.

The men's helper lit the five candles and lit the incense in the pan and began passing the incense around and about the mesa. I was instructed to turn on the tape recorder and the third chant began. It was $3: 10$ p.m.

Men continued working on the breads on the ground as the chanting proceeded. Again, at the end of the chant, the men kneeled, spoke silently, and made a kissing motion toward the mesa.

After this chant, the men finished breaking up the breads. The large pile of bread crumbs was poured into the pot of soup on the ground. Hearts, livers and heads from the butchered fowl were added. The mixture was thoroughly stirred with a pole, making a very thick soup known as $k^{\prime}$ ol. Seven gourd cups were filled with the new $k^{\prime} o l$ and were arranged by the men on the mesa with the six bowls left in place from the third chant. He then set another bowl of $k^{\prime} \circ l$ in front of him to be used when sprinkling $k^{\prime} \circ l$ to the four directions. The candles had been left burning. The men's helper once again lit the incense and the fourth and final chant began.

Part way into this chant, the men gestured to the pile of cigarettes, then paused and distributed the cigarettes to those present. Some began them, some didn't. Near the end of this chant he kneeled and continued chanting. Then he stood and while chanting, sprinkled $k^{\prime} o l$ in four directions about the mesa.

At the end, he called over Luis Xool and instructed him on how to say his promesa, or pledge. Luis repeated the words of the men, gesturing over the mesa. When Luis finished, the chanting was over.

The food on the mesa was passed out to the men gathered in the area. The remaining $k^{\prime} o l$ in the pot was taken to the house area and distributed. There was plenty to eat for all. An estimated forty persons. including children, were fed from the food prepared 
for the Wahil Kol ceremony. The men ate along with everyone else.

As people were finishing their meal, the men went to the dying fire pit and sprinkled balche' in the form of a cross on the cooling stones. Then he went back and briefly gestured and spoke silently over the mesa. As people began cleaning up in the house and the yard, the men took down his crucifix and motioned to me to get my tape recorder and notebook. We left the yard of Luis Xool at 5.30 p.m.

\section{Introduction to the Chants}

The chants presented below were recorded on a portable cassette recorder with the microphone attached to the front of the mesa. A rough transcription and translation into Spanish was then made by Don Eduardo Peraza Castillo, a resident of Becanchen. Then, using the original tape along with Peraza's work and three Maya dictionaries, the final transcription and translation were made by myself.

The transcription is a normalized one. For example, glottalization in the word $t i^{\prime} a^{\prime} l$ is not heard in casual speech. Phonetically it would be transcribed $/ t^{\mathrm{y}} \mathrm{al} /$, but I have chosen to follow the spelling used in the newly published Diccionario Maya Cordemex.

The Diccionario Maya Cordemex is easily the best Yucatec Maya dictionary published to date. The result of six years of intensive labor by Maya speaking scholars under the directorship of Alfredo Barrera Vásquez, in Mérida, it includes all the important colonial sources such as the Motul Dictionary and the Pérez Dictionary, in addition to the Maya spoken in the peninsula today. It is hoped that this work will become accepted as the standard reference for Maya scholars of all nationalities.

As stated in the introduction to the dictionary, the alphabet used is more pragmatic than scientific. There is no word that cannot be written on an ordinary typewriter. All consonants are pronounced the same as in English except " $x$ " which has the sound "sh". Vowels are pronounced the same as in Spanish. An apostrophe denotes glottalization. A doubled vowel indicates vowel length.

The text is divided into lines determined by the places where the me $\eta$ paused to take a breath. I have put a question mark where I was unable to translate a morpheme. A short line between quotation marks, "_," indicates a break in the chanting where the men spoke to someone in the group near the mesa. An asterisk denotes Spanish words. 


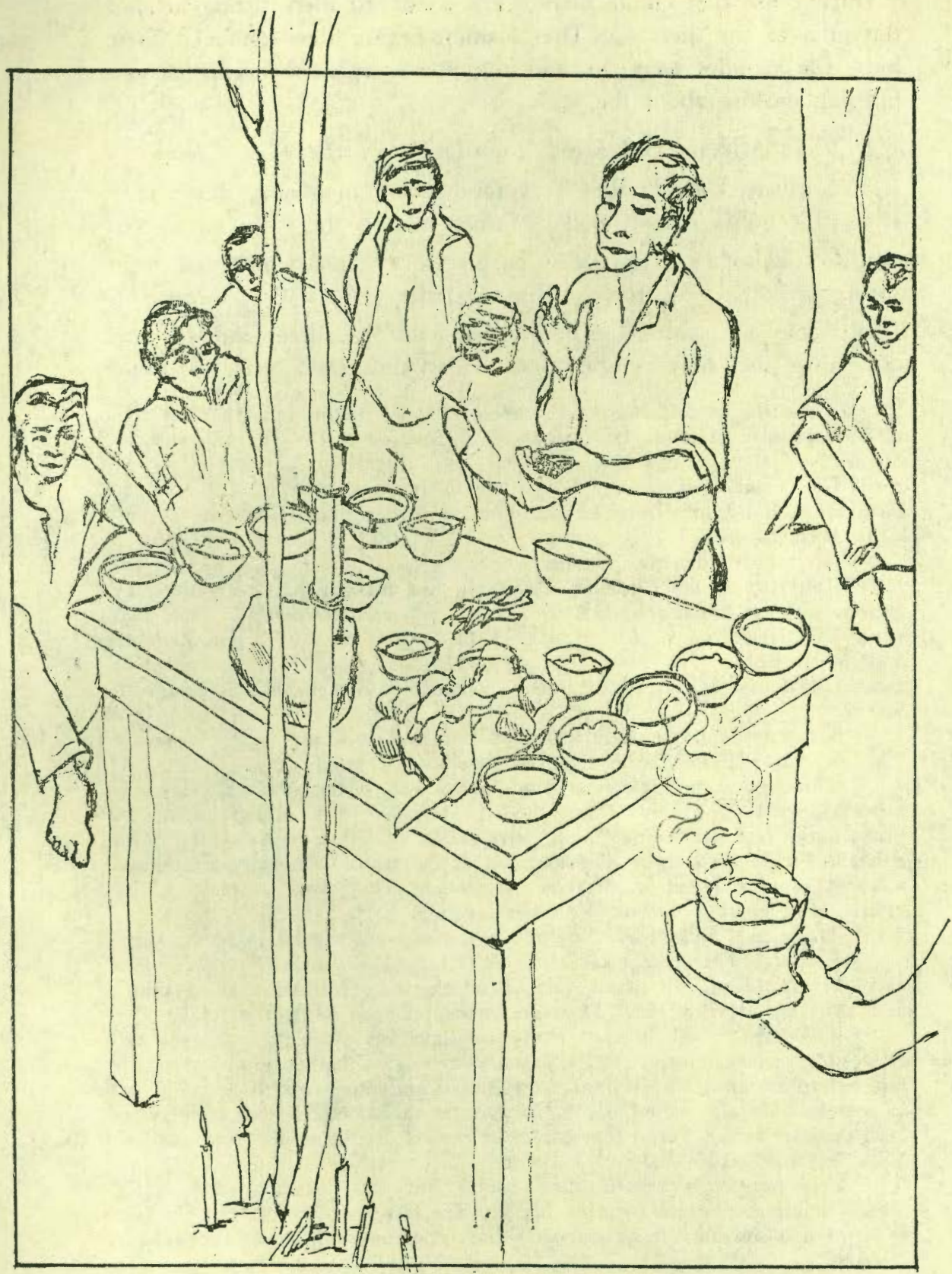

Figure 3. Offering the cigarettes during the fourth chant. 
During the first chant there were about 10 men sitting around the area of the mesa. As Don Ramón began, they removed their hats, the candles were lit and the men's assistant began passing burning incense about the mesa.

\section{Transcription and Strict Translation of the First Chant}

1. $\mathrm{tu}^{15}$ kilich $\mathrm{k}^{\prime} \mathrm{aba}{ }^{\prime 16}$ dios*17 yumbil dios* mehenbil dios* del* 1. in this holy name god father god son god of the espíritu* santo*.18 2. u ti'a' ${ }^{19}$ bakan xan ${ }^{20}$ in wa'tal ${ }^{21}$ bakan in spirit holy. 2. for thus also I stand thus I k'ub bakan e santo*22 suhuy ${ }^{22}$ primicias $^{* 23}$ bakan xan tu noh offer thus the holy virgin first fruits thus also on his great

${ }_{15} T u$ is the combination of $t i$, the locative or prepositional particle and $u$, the possessive pronoun. It is translated in Spanish as "en su" (Diccionario Maya Cordemex 1980:810).

${ }_{16}$ Glottalization is usually lost in the very rapid speech of this ritual incantation, but $\mathrm{I}$ have retained the notation in accordance with the Diccionario Maya Cordemex.

17 An asterisk denotes Spanish words.

18 Referring to the Christian Trinity in this manner has been noted by various authors. Thompson, J. E. S. (1930:116) transcribed it " $U$ qaba Dios yume Dios Hijo Dios Espiritu Santo." Villa Rojas (1945:160) and Redfield and Villa Rojas (1934:339, 341, 343, 346, 347, 353, 354) recorded it exactly as found in this chant, "Dios yumbil, dios mehenbil, dios espiritu santo."

${ }_{19}$ My informant, Peraza, transcribed this as one word, "utial", meaning "for" or "in order that", the Spanish "para".

20 Throughout the chants we hear "bakan xan, bakan xan." These words provide rhythm and flow. Gann (1918:47) recorded a similar ocurrence, "yetel bakan tech [this being]" and "yetel bakan tech [that being]" going down a whole list of personages. The meaning of the words it not important and has not been included in the free translation. They work more as a linguistic glue, binding the many phrases together.

21 The men is indeed standing before the mesa. The men in Socotz, British Honduras (Thompson, J. E. S. 1930:115, 116) said "Kin watal kin kawatal, ošwalahen," "I stand once, I stand twice, I stand a third time", and also "kin watal in tane" "I stand in the presence or in front of."

22 The term suhuy is most easily translated as virgin but it does not refer only to the absence of sexual intercourse. Although virgin girls are referred to as suhuy, things that are cleansed and sanctified to be presented to the gods are also called suhuy. Items such as hammocks that have never been used are suhuy. Forest that has never been cleared is suhuy (Redfield and Villa Rojas 1934:130-131).

${ }^{23}$ Primicias is translated "first fruits" but this ceremony took place during planting season, not during harvest. The men could be offering the first fruits of a future harvest, or primicias may be understood simply to mean an offering.

24 A good English translation of "mesa" might be "altar".

${ }^{25} Y$ umtsilo $b$ refers collectively to the invisible guardians or protectors of the fields and town (Redfield and Villa Rojas 1934:112-113). 
mes2*24 bakan xan ti yumtsilo'b ${ }^{25}$ bakan xan. 3. u ti'a'l bakan mesa thus also to lords thus also. 3. for thus $\mathrm{xan}$ in ki pektsilob ${ }^{26}{ }^{27}$ bakan $\mathrm{xan}$ tu kan titsi] also I with pleasure move them thus also in the four corner ka'an tu kan tits lu'um. ${ }^{2 s}$ 4. way bakan xan in wa'tal bakan sky in the four corner land. 4. here thus also I stand thus in k'amob bakan xan ti'a'l bakan u ki tal u I receive them thus also for thus they with pleasure come they ki tsolben t'anob ${ }^{29}$ xan way bakan tu suhuy mesa*. with fleasure set in order also here thus on the virgin mesa.

5. tu suhuy mesa* bakan xan ti bakan xan tin wa't in 5. on the virgin mesa thus also to thus also $I$ am stand I k'amob bakan xan ti'a'l bakan xan u pektsilob bakan xan receive them thus also for thus also they move them thus also way bakan tu noh mesa* dios* yumbil tu noh mesa* dios* here thus on the great mesa god father on the great mesa god espíritu* santo* 6. u ti'a'l bakan xan in pektsilob bakan xan spirit holy. 6. for thus also I move them thus also

tu $\tan ^{30}$ nohol $^{31}$ tu $\tan$ chik'in tu tan xaman. in the front south in the front west in the front north.

${ }^{26}$ Although $o b$ is the plural suffix for nouns, it can also be used with verbs as an object pronoun. In pektsil, "I mobilize" becomes in pektsilob, "I mobilize them" (Blair and Vermont-Salas 1965:340, 454-455).

${ }^{27}$ I have translated pektsil "move" but the sense of the word is more like "stir" or "vibrate" (Diccionario Maya Cordemex 1980:643).

28 In Chan Kom (Redfield and Villa Rojas 1934:340, 342, 344, 346), the men often referred to " $t u$ can titzcaan, can titzmuyal," "four corners of the sky, four corners of the clouds."

29 Tsolben t'anob has been most difficult to translate. The morpheme tsol as a verb means "put in order," "make orderly;" as a noun it is "a line" or a "series" or "procession" (Diccionario Maya Cordemex 1980:863). Combined with the morpheme $t$ 'an "word or language", it means "interpret or translate" and Ah tsol t'an is "he who interprets" or "he who puts words in order" (Diccionario Maya Cordemex 1980:864). Thompson, J. E. S. (1930: 116) recorded the same phrase in Socotz, "Ea in yume y tsolben tan Diosobe" but translated " $u$ tsolben tan" as "the good intentions in the presence of". Peraza, my informant, translated tsolben t"anob one time as "hablamos hordenadamente" but all the rest of the times "ordenar".

${ }^{30}$ Tú $\tan$ could be translated as "in the presence of."

31 In all but one case, when the men calls out the world directions, he begins with the south and ends with the east. 
7. way bakan xan in wa'tal bakan in k'amob bakan tu tan

7. here thus also I stand thus I receive them thus in the front

lak'in ti yum t'up k'ab balam ${ }^{32}$ ti tox k'ab balam ti nohoch east to father littlest hand jaguar to pour hand jaguar to great

balam. 8. u ti'a'l bakan xan u ki tal u jaguar. 8. for thus also they with pleasure come they ki tsolben t'anob xan tu k'aba' dios* yumbil dios* with pleausure set in order also in the name god father god mehenbil dios* del* espiritu* santo*. 9. way bakan xan ti'a'l son god of the spirit holy. 9. here thus also for

bakan in t'ankob xan $\mathrm{u}$ chi $\mathrm{u}^{33}$ pektsil bakan xan e yumtsilo'b thus I call them also ? move thus also the lords

bakan xan ti'a'l bakan u ki tal u ki thus also for thus they with pleasure come they with pleasure tsolben t'anob. 10. way bakan xan in wa'tal bakan in k'amob set in order. 10. here thus also I stand thus I receive them bakan xan ti'a'l bakan xan in k'ubik bakan xan yetel le santo* thus also for thus also I offer it thus also with the holy

suhuy vino*34 bakan xan. 11. tin pektsilob bakan xan ti'a'l virgin wine thus also. 11. I am move them thus also for

bakan $\mathrm{u}$ ki tal $\mathrm{u}$ ki tsolben t'anob thus they with pleasure come they with pleasure set in order bakan xan way bakan tu suhuy mesa* bakan xan ti yumtsilo'b. thus also here thus on the virgin mesa thus also to lords.

32 "Jaguar" is one translation of balam. Actually the balamob mentioned here are spirit beings very similar to the yumisilob. They are guardians and protectors (Diccionario Maya Cordemex 1980:32, Redfield and Villa Rojas 1934:113). For a discussion of the balamob and other spirits mentioned in these chants, see pp.290-293.

33 Throughout these chants, always associated with the word pektsil or pektsilob are these morphemes which I have been unable to translate. Sometimes they sound like $u$ chu; other times like $u$ chi $u$ or just $u$ chi.

34 The vino he is referring to is the balche in the cups on the four corners of the mesa. See page 253 for a description of the balche'. 
12. ti yumtsilo'b bakan xan tin wa't in k'amob bakan xan 12. to lords thus also $I$ am stand $I$ receive them thus also tu noh mesa* dios* yumbil tu noh mesa* dios* espíritu* on the great mesa god father on the great mesa god spirit santo*. 13. u ti'a'l bakan xan u ki tal u holy. 13. for thus also they with pleasure come they ki tsolben t'anob xan way bakan xan tin k'ubik with pleasure set in order also here thus also I am offer it bakan xan ti bakan e santo* suhuy uk'ul ${ }^{\text {ss }}$ yetel $u$ suhuy thus also to thus the holy virgin drink with the virgin chamalob $^{36}$ bakan xan. 14. Yetel u suhuy ulilis7 bakan xan tin cigarettes thus also. 14. With the virgin drink thus also I am k'ubik bakan tu noh mesa* dios* yumbil tu noh mesa* offer it thus on the great mesa god father on the great mesa dios* espíritu* santo*. 15. way bakan xan in wa'tal bakan in god spirit holy. 15. here thus also I stand thus I

k'amob bakan xan ti'a'l bakan u ki tal u receive them thus also for thus they with pleasure come they ki tsolben t'anob xan way bakan xan in t'ankob xan. with pleasure set in order also here thus also I call them also. 16. u ti'a'l bakan xan $u$ chi pektsilob bakan xan tu kan titsil 16. for thus also ? they move thus also in the four corner ka'an tu kan tits lu'um. 17. way bakan xan in ki sky in the four corner land. 17. here thus also I with pleasure wa'tal bakan in k'amob bakan xan ti'a'l bakan u ki stand thus I receive them thus also for thus they with pleasure

85 The drink referred to here is the saka'. See pages 255-256.

36 See page 256 for use of cigarettes during the ceremony.

37 Uk'ul. 
tal $\mathrm{u}$ ki tsolben t'anob xan way bakan xan tu come they with pleasure set in order also here thus also on the suhuy mesa* dios* yumbil. 18. tu suhuy mesa* dios* espíritu* virgin mesa god father. 18. on the virgin mesa god spirit santo*. 19. u ti'a'l bakan xan in wa'tal bakan in k'ub bakan xan holy. 19. for thus also I stand thus I offer thus also e santo* suhuy primicia* bakan xan ti'a'l bakan u ki the holy virgin first fruits thus also for thus they with pleasure tal u ki tsolben t'anob xan. "__" "38 20. u ti'a'l come they with pleasure set in order also. "_" 20. for bakan xan $\mathrm{u}$ ki talob bakan xan $\mathrm{u}$ ki thus also they with pleasure they come thus also they with pleasure tsolben t'anob xan way bakan tu noh mesa* bakan xan. set in order also here thus on the great mesa thus also.

21. way bakan xan in wa'tal bakan in k'amob bakan xan $u$ 21. here thus also I stand thus I receive them thus also they ki tal bakan xan way bakan xan yetel bakan xan in with pleasure come thus also here thus also with thus also I

t'anik bakan xan. 22. ti $x^{39}$ kichkelem tata dios* padre* ti call it thus also. 22. to ? beautiful father god father to dios* hijo* dios* del* espíritu* santo*. 23. u ti’a'l bakan xan god son god of the spirit holy. 23. for thus also

$\mathrm{u}$ chi pektsilob bakan xan yetel $\mathrm{u} \quad \mathrm{ah}^{40}$ meyahob tu ah ? they move thus also with the masc. workers to the masc. hoya'ob ah tepalob xan. 24. u ti'a'l bakan xan u waterers masc. powerful ones also. 24. for thus also they

${ }^{38}$ Here the men pauses to ask Luis Xool how many mecates are in his milpa. $39 x$ is a female prefix and occurs frequently, later in the chants, with the names of female personages. It is unclear why it is used in front of god the father.

40 ah is the masculine prefix. 
ki tal $\mathrm{u}$ ki tsolben t'anob xan way bakan with pleasure come they with pleasure set in order also here thus xan e servicio* bakan xan tu noh mesa* dios* yumbil. also the service thus also on the great mesa god father.

25. dios* mehenbil dios* del* espíritu* santo*. 26. gloria* al* 25. god son god of the spirit holy. 26. glory to the padre* gloria* al* hijo* gloria* del* espíritu* santo* father glory to the son glory to the spirit holy.

27. way bakan xan in wa'tal bakan in payalchi'kob bakan xan u 27. here thus also I stand thus I pray to them thus also they ki tal $\mathrm{u}$ ki tsolben t'anob bakan xan way with pleasure come they with pleasure set in order thus also here baxan xan u ki tal u ki tsolben t'anob thus also they with pleasure come they with pleasure set in order xan way bagan tu noh mesa*. "_," 28. u ti'a'l bakan also here thus on the great mesa. "__" 28. for thus xan in k'ubik bakan xan tu k'aba' bakan tech ta k'aba' also I offer it thus also in the name thus you your name tech. 29. u ti'a'l bakan xan in k'ubik bakan xan e setenta* you. 29. for thus also $I$ offer it thus also the seventy

mecates $^{42}$ bakan xan way bakan xan tu kaxil bakan xan ti mecates thus also here thus also in the forest thus also to

nacional* bakan xan. 30. way bakan xan ti bakan xan in ki national thus also. 30 . here thus also to thus also I with pleasure k'ubik bakan xan ti'a'l bakan xan u lu'usal bakan xan yetel offer it thus also for thus also his protection thus also with

41 Here the men once again asks Luis Xool how many mecates are in his milpa. He answers "seventy". He then asks whether his milpa is on ejido land of Becanchen or in the national lands. Luis answers "national".

42 Mecate is a Náhuatl word. It is a square unit of land measure, 20 meters to a side. 
bakan xan. 31. u tu lu'usal yok'ol bakan xan Luis Xool thus also. 31. his for his protection over thus also Luis Xool

bakan xan. 32. ti bakan xan kin lu'usik yok'ol bakan xan yok'ol thus also. 32. to thus also ? protect it over thus also over

u familia* bakan xan yetel u yok'ol u palalob bakan xan ti his family thus also with his over his children thus also to

bakan xan kin k'ubik bakan xan tu k'aba' dios* yumbil. thus also I offer it thus also in the name god father.

33. tu k'aba' dios" espíritu* santo*. 34. leti santo* suhuy 33. in the name god spirit holy. 34. that holy virgin

primicia* bakan xan tin k'ubik bakan xan ti'a'l bakan xan first fruits thus also I am offer it thus also for thus also

k'ubik bakan xan ti ah kalan kolob ti ah kalan offer it thus also to masc. guardian milpa to masc. guardian

xu'uk'ob kalan misob hil p'isib che' ti e k'en boundary stones guardian sweeping drag measuring pole to the twist

ke'eles ikob ti e t'ul pach ik'ob ti e moson ti ik'ob. ${ }^{43}$ fright winds to the place behind winds to the whirl to winds.

35. ti bakan xan tin wa't in k'amob bakan xan tu suhuy 35. to thus also I am stand I receive them thus also on virgin mesa* dios* yumbil. 36. tu suhuy mesa* dios* espíritu* santo*. mesa god father 36 . on the virgin mesa god spirit holy.

37. way bakan xan bakan xan in k'ubik bakan xan yetel bakan 37. here thus also thus also I offer it thus also with thus

e santo* suhuy uk'ul yetel $u$ suhuy vino* yetel $u$ suhuy the holy virgin drink with the virgin wine with the virgin chamalob bakan xan ti'a'l nukuch ak'ab xuxubobo xan. cigarettes thus also for great night whistling spirits also.

48 For a discussion of these guardians and winds, see pages 290-293. 
38. ti bakan xan kin wa'tal bakan in k'ub bakan xan tu noh. 38. to thus also I am stand I offer thus also on the great mesa* bakan xan ti kichkelem tata dios* u chi pektsilob bakan xan. mesa thus also to beautiful father god ? move them thus also.

39. yetel bakan xan ti yum t'up k'ab balam ti tox k'ab 39. with thus also to father littlest hand jaguar to pour hand

balam ti nohoch balam. 40. u ti'a'l bakan xan u ki jaguar to great jaguar. 40. for thus alto they with pleasure tal $\mathrm{u}$ ki tsolben t'anob xan tu k'aba' dios* come they with pleasure set in order also in the name god yumbil. 41. dios* mehenbil dios* del* espíritu* santo*. father. 41. god son god of the spirit holy.

42. gloria* al* padre* gloria* al* hijo* gloria* de* espíritu* 42. glory to the father glory to the son glory of spirit

santo*.

holy.
43. Heen ${ }^{44}$ kanaknak $^{45}$
hatsaknak $^{46}$
misiknak
43. ? placed in corners divided into parts swept nopoknak $\operatorname{bin}^{47}$ u ki pokol u suhuy mesa* dios* washed ? they with pleasure wash their virgin mesa god

$44 U_{p}$ to this point, the incantation has been very rapid and rather monotonic. But here there is a break. Then beginning with a long high heen, the chant takes on a singsong quality. The following words, kanaknak, hatsaknak, nopoknak, misiknak, are probably used as much for their rhythmic and consonant qualities as for their meaning.

45 Kanaknak was translated by Peraza as "arrinconada", "placed in a corner". K'anaknak in the Diccionario Maya Cordemex (1980:375) means "focd that produces an agreeable odor."

46 Hatsaknak was translated by Peraza as "acentado", "seated" or "placed". The same word appears in a chant from Chan Kom (Redfield and Villa Rojas $1934: 352)$ translated aa "that the rain may come." More likely it refers to being divided into portions or parts. See under Hats in Diccionario Maya Cordemex (1980:182-3).

47 Bin is both the verb "to go" and a particle indicating the future imperfect (Diccionario Maya Cordemex 1980:55). I have decided not to translate it at this time. 
yumbil u mesa* dios* espíritu* san*. 44. u ti'a'l bin xan u father their mesa god spirit holy. 44. for ? also they ki tal bakan $x$ an $\mathrm{u}$ ki ximbal $x a n u$ with pleausure come thus also they with pleasure walk also their suhuy mesa* dios* yumbil u mesa* dios* espíritu* santo* virgin mesa god father their mesa god spirit holy.

45. u ti'a'l bakan xan in ki payalchi'tik bakan xan 45. for thus also I with pleasure pray thus also u $\mathrm{ki}$ tal bakan xan yetel ti $\mathrm{x}$ kichpam kolebil $\mathrm{x}$ they with pleasure come thus also with to fem. beautiful virgin fem.

ayik'al $^{48}$ ti $\mathrm{x}$ kichpam kolebil sayab. 46. u ti'a'l bin xan riches to fem. beautiful virgin fountain. 46. for ? also ki tal bakan xan in ki sutuba bakan xan with pleasure come this also I with pleasure turn around thus also yetel $\mathrm{x}$ kichpam kolebil tres* personas* ti $\mathrm{x}$ kichpam kolebil with fem. beautiful virgin three persons to fem. beautiful virgin xunantunich kichpam kolebil $\mathrm{x}$ ma'nikben. 47. ti $\mathrm{x}$ kichpam lady of stone beautiful virgin fem. everlasting. 47. to fem. beautiful kolebil Santa Ana Santa Lucía perfecto* socorro* ti x kichpam virgin Santa Ana Santa Lucía perfect solace to fem. beautiful kolebil librada* ti $x$ kichpam kolebil Asunción* x kichpam virgin saved to fem. beautiful virgin Assumption fem. beautiful

kolebil Fátima. 48. ti $\mathrm{x}$ kichpam kolebil Guadalupe ti $\mathrm{x}$ virgin Fátima. 48. to fem. beautiful virgin Guadalupe to fem.

48 Here begins a long list of names of holy personages or sacred objects that the men refers to at the end of all four chants. This is a common element in Mayan agricultural ceremonies. Tozzer (1907:161) wrote "a chant is then made, and all the saints of each pueblo are invited to come and partake of the offering." Gann (1918:47) also recorded the naming of many. saints and names of towns in the body of the incantations. Part of the ceremony Villa Rojas (1945:159) described had the line "Three times my word goes out to [the name of a town or ranch]", repeated over and over, each time changing the name of the town or ranch. In Chan Kom (Redfield and Villa Rojas 1934:137), the same phrase was used substituting villages, archaeological ruins and cenotes. 
kichpam kolebil suhuy Santa María. 49. way bin xan in t'anik beautiful virgin virgin Santa María. 49. here ? also I call it

bakan xan ti x kichpam kolebil Marta xan. 50. u ti'a'l bin thus also to fem. beautiful virgin Marta also. 50. for ?

xan $\mathrm{u}$ ki tal ? yetel $\mathrm{u}$ ah meyahob tu ah also they with pleasure come? with their masc. workers to their masc.

hoya'ob ah tepalob xan. 51. way bin xan in t'ankob waterers masc. powerful ones also. 51. here ? also I call them tu suhuy mesa* dios* yumbil tu mesa* dios* espíritu* santo*. on the virgin mesa god father on the mesa god spirit holy.

52. u ti'a'l bin xan in payalchi'kob bakan xan u ki 52. for ? also I pray to them thus also they with pleasure tal bakan xan ti yum Señor San Juan Bautista ti yum San Pedro come thus also to father Señor San Juan Bautista to father San Pedro San Isidro ti yum santa* cruz*Baxak' ti yum Señor San Antonio. San Isidro to father holy cross Baxak' to father Señor San Antonio.

53. Señor San José San Joaquin San Felipe Señor San Lorenzo 53. Señor San José San Joaquin San Felipe Señor San Lorenzo

San Buenaventura San Francisco y San Dimas. 54. Ti yum santos* San Buenaventura San Francisco and San Dimas. 54. To father holy tres* reyes* ti Tizimin ${ }^{49}$ San Romani Campech Señor Santiago [Halach'o ${ }^{50}$ three kings to Tizimin San Romani Campeche Señor Santiago [Halach'o

ti yum santo* Cristo* Chumayel San Miguel Arcángel yum niño* to father holy Christ Chumayel San Miguel Archangel father child

40 This refers to images of the "three wise men" in a cathedral in the Yucatecan town of Tizimin.

${ }^{50}$ Halach'o is a town in Yucatán.

51 Chumayel is a town in Yucatán. 
de* Atocha. 55. Corazon* de* Jesus Señor Martín. 56. u ti'a'l bakan of Atocha. 55. Heart of Jesus Señor Martín. 56. for thus

xan in t'anik bakan xan ti yum Señor San Bernardino xan yetel also I call it thus also to father Señor San Bernardino also with

$u$ ah meyahob yetel $u$ ah hoya'ob ah tepalob xan. the masc. workers with the masc. waterers masc. powerful ones also.

57. way bakan xan in t'ankob bakan tu suhuy mesa* dios* 57. here thus also I call them thus on the virgin mesa god yumbil tu suhuy mesa* dios* espíritu* santo*. 58. gloria* al* father on the virgin mesa god spirit holy. 58. glory to the padre* gloria* al* hijo* gloria* de* espíritu* santo* Amen. father glory to the son glory of spirit holy Amen.

\section{E. Free Translation of the First Chant}

1. In the holy name of the father, the son and the holy spirit. 2. I stand, I offer the holy virgin first fruits on the great mesa to the lords. 3. I move them in the four corners of the sky, in the four corners of the land. 4. I stand, I receive them. They come with pleasure, they set in order the virgin mesa. 5. I stand, I receive them. They move here on the great mesa of god the father, on the great mesa of god the holy spirit. 6. I move to the south, to the west, to the north. 7. I stand, I receive them in the east, the littlest hand of the jaguar, the hand of the jaguar that pours, the great jaguar. 8. They come with pleasure, they set in order in the name of god the father, god the son, and god the holy spirit. 9. I call to the lords to move, to come with pleasure, to set in order. 10. I stand, I receive them. I make an offering. of the holy virgin wine. 11. I move the lords. They come with pleasure, they set in order the virgin mesa. 12. I stand, I receive the lords on the great mesa of god the father and god the holy spirit. 13. They come, they set in order. I make an offering with the holy virgin drink and the virgin cigarettes. 14. I make an offering of the virgin drink on the great mesa of god the father, on the great mesa of god the holy spirit. 15. I stand here, I receive them. They come with pleasure, they set in order. I call to them. 
16. They move in four corners of the sky, on the four corners of the land. 17. I stand, I receive them. They come with pleasure, they set in order the virgin mesa of god the father. 18. The virgin mesa of god the holy spirit. 19. I stand, I make an offering of the holy virgin first fruits. They come with pleasure, they set in order. 20. They come with pleasure, they set in order the great mesa. 21. I stand here, I receive them, they come. I call out. 22. To the beautiful father, god the father, god the son, god the holy spirit. 23. They move. The workers, the waterers, the powerful ones. 24. They come with pleasure to this service on the great mesa of god the father. 25. God. the son, god of the holy spirit. 26. Glory to the father. Glory to the son. Glory of the holy spirit. 27. I stand here, I pray to them. They come with pleasure. They set in order the great mesa. 28. I make an offering in your name. 29. I make an offering of seventy mecates of national forest. 30. I make an offering for protection. 31. For protection over Luis Xool. 32. For protection over his family and over his children. I make an offering in the name of god the father. 33. In the name of god the holy spirit. 34. I make an offering of the holy virgin first fruits to the guardians of the milpa, to the guardians of the boundary stones, to the guardians of the sweeping, to he who measures the forest, to the evil winds, to the winds that follow, to the whirlwinds. 35. I stand, I receive them on the virgin mesa of god the father. 36. On the virgin mesa of god the holy spirit. 37 . They come with pleasure, they set in order. I make an offering of the holy virgin drink, the virgin wine, and the virgin cigarettes to the great norturnal whistling spirits. 38. I stand, I make an offering on the great mesa to the beautiful father god. They move. 39. And father littlest hand of the jaguar, hand of the jaguar that pours, and the great jaguar. 40 . They come with pleasure, they set in order in the name of god the father. 41. God the son, god of the holy spirit. 42. Glory of the holy spirit.

43. Placed in corners, diviced into parts, swept and washed, cleansed is the virgin mesa of god the father, the mesa, of god the holy spirit. 44. They come with pleasure. They walk on the virgin mesa of god the father, god the holy spirit. 45. I pray to them. They come with pleasure. The beautiful virgin of riches, the beautiful virgin of the fountain. 46. They come with pleasure. They turn around. The beautiful virgin of the three persons, the beautiful virgin lady of stone, the beautiful virgin everlasting. 47 . The beautiful virgin Santa Ana, Santa Lucía, perfect solace, the beau- 
tiful virgin of the saved, the beautiful virgin of the Assumption, the beautiful virgin of Fátima. 48. To the beautiful virgin of Guadalupe, the beautiful virgin Santa María. 49. I call out to the beautiful virgin Marta. 50. They come with pleasure with the workers, the waterers, the powerful ones. 51. I call to them on the virgin mesa of god the father, god the holy spirit. 52. I pray to them. They come with pleasure. Señor San Juan Bautista, San Pedro, San Isidro, holy cross of Baxak', Señor San Antonio. 53. Señor San José, San Joaquín, San Felipe, Señor San Lorenzo San Buenaventura San Francisco and San Dimas. 54. To the holy three kings of Tizimin, San Romani Campeche, Señor Santiago of Halach'o, holy Christ of Chumayel, San Miguel Archangel, child of Atocha. 55. Heart of Jesús, Señor Martín. 56. I call out to Señor San Bernardino, the workers, the powerful ones. 57. I call to them on the virgin mesa of god the father, god the holy spirit. 58. Glory to the father. Glory to the son. Glory of the holy spirit. Amen.

(At the end of this chant, balche' is distributed to the participants.)

\section{Part II Comprarative Analysis}

Comparisons in this paper are limited geographically and linguistically to Yucatec-speaking Maya of Yucatán, Quintana Roo and northern Belize.

\section{A. Defining the Ceremonies}

The difficulty with comparing the present day Wahil Kol ceremony with the ceremonies described in the literature lies in the variety of ceremonies and the lack of uniform names for them. What is called Wahil Kol in Becanchen is called U Hanli Kol in Chan Kom, and what in one area is a three-day event performed yearly in the field may, in another area, be a half-day event performed in the village plaza.

In Chan Kom (Redfield and Villa Rojas 1934:138) the Ch'a Chaak ceremony was performed only during years of severe drought. In Becanchen, it was performed annually.

But there does seem to be a central theme uniting these ceremonies. That theme is agriculture or fertility. Villa Rojas (1945) has 
termed these ceremonies agricultural ceremonies and this seems to be a fitting and useful designation. The ceremonies are tied closely to the yearly agricultural cycle of clearing, burning, planting and harvesting. The deities addressed are the guardians and workers of the forests and fields, and the offerings made are the fruits of agricultural pursuits.

\section{B. Agricultural Ceremonies in the Literature}

Many early Spanish relaciones of Yucatan (especially Landa's) and many examples of native Yucatec Maya literature (such as the Books of Chilam Balam, the Ritual of the Bacabs and the Maya pictorical codices) reveal certain elements of religious practice also found in the Wahil Kol ceremony of Becanchen in 1978. However, specific mention of agricultural ceremonies, clearly identified as such and similar to the ceremony described in this paper, does not occur until the 19th century.

The earliest reference I have found is in an article by Brinton (1883:244-249). His article is a kind of summary of earlier material which he had in his possession (a manuscript by a native of Tihosuco, two sets of notes by Don José María López of Mérida and Dr. Berendt [dates not given], and a report from Yaxcaba' written in 1813). In the article, Brinton describes a ceremony known as misa milpera, or "mass of the milpa." Unfortunately, Brinton does not say when, where or by whom the ceremony was witnessed.

In Maya, according to Brinton's source, the ceremony was called tich'. Tich' is defined in the Pérez Dictionary (1866-77:326) of the 19th century as "sacrificio ó ceremonia que practicaban los indios antes de cosechar sus sementeras para tener propicio al genio del monte," clearly an agricultural ceremony.

What little description there is of the ceremony fits nicely with more recent observations. There was the mesa, the consecration of the fowl with balche', special "maize cakes", the sprinkling of balches to the four cardinal points, the calling to the three persons of the Christian Trinity and to "the sacred four of his own religion."

Brasseur de Bourbourg, in 1870, recorded an "invocation to the four cardinal points" in the interior of Yucatán, but I have yet to get hold of this source. An English translation of that chant is given in Brinton's (1883:249) article which has a distinct similarity to the incantations from Becanchen. 
More recently, we begin to find specific references to $c h^{\prime} a$ Chaak, Wahil Kol and Hanli Kol ceremonies. E. H. Thompson (1932:5362), the U.S. Consul living in Mérida at the turn of the century, described a Ch'a Chaak ceremony that he attended near Mérida.

Tozzer (1907:160-163) made his ethnographic observations in Yucatán between 1902 and 1905. He described the rites of $U$ Hanli Kol, Cha' Chaak and others.

Gann's (1918:47) observations of a Ch'a Chaak ceremony come from southern Quintana Roo and were made between 1900 and 1916(?).

There are two sources from the 1920's. They are Pacheco Cruz's (1947:102-108) observations of Ch'a Chaak and a Wahil Kol ceremony near Valladolid in 1927 and J. E. S. Thompson's (1932:41$55,62-64,72,115-117)$ ethnographic descriptions of agricultural ceremonies in British Honduras between 1927 and 1929.

Steggerda's description of a Hanli Kol ceremony is too brief to be of much more use than to confirm that the ceremony was being performed in Yucatán in 1938.

By far, the two best ethnographies describing Maya performing agricultural ceremonies come from the 1930's. These were written by Villa Rojas (1945:111-117) and Redfield and Villa Rojas (1934: 127-147). Both works were carried out under the auspices of the Carnegie Institute of Washington, and provide our best information to date on the subject. Villa Rojas' information comes from Quintana Roo; Redfield and Villa Rojas' from eastern Yucatan.

The Wahil Kol ceremony described in this paper took place in 1978 near the southern tip of the State of Yucatán, in Becanchen.

In the sources mentioned above, four give transcriptions, or partial transcriptions, of chants (Gann 1918:46-7, Thompson, J. E. S. 1930:115-116, Villa Rojas 1945:159-60, Redfield and Villa Rojas 1934:339-356).

Of course, there must be more descriptions of these ubiquitous agricultural rites in the literature, but even among the ten or so that I have found, there are remarkable similarities and consistencies stretching over the last 100 years. And there are some interesting differences. 


\section{Similarities in the Ceremonies}

One obvious similarity in all the ceremonies I have found described in the literature is that the ceremonies are led by a men. The term, meaning "he who knows", is found consistently in the references. The menob (plural of men) mentioned often perform curing and divination. They do not lead Catholic ceremonies which are led by priests and maestros cantores.

The physical set-up for the ceremonies is quite similar throughout the examples cited. The central physical prop is the mesa. The introduction of modern tables to replace the mesas built of bound sticks on forked poles does not seem to have altered the ceremony in any way. In several descriptions of $C h^{\prime} a$ Chaak ceremonies branches are set up around the mesa and tied at the top forming an arch.

The use of a cross or crosses is also mentioned frequently. Whether the cross is a Christian symbol or is of pre-Columbian origin, as some have suggested, is not known. It is only known that crosses have been used along with the mesa since the earliest recording of the ceremonies.

Candles are present in most accounts. Their number and color varies. Generally they are placed on the mesa, but in Becanchen they were placed on the ground under the east side of the mesa.

Burning incense accompanies the men's chanting in just about all the accounts.

The offerings presented to the native deities are very consistent. Balche, with some slight variation in ingredients, is used throughout the ceremonies as the holy drink that purifies or sanctifies. It is given to the fowl before they are slaughtered, it is sprinkled to the world directions, and it is drunk by the men and other participants.

$S a k a^{\prime}$, the specially prepared maize drink, is mentioned consistently. This, according to Redfield and Villa Rojas (1934:39) was definitely a ceremonial drink, not secular.

Specially prepared maize cakes or breads provide the largest portion of the ceremonial food prepared for these occasions. There is variation in the preparation of these cakes but they all seem to be made with a specified number of layers, with sikil paste spread between the layers. 13 is the most often used number of layers, but $9,8,7,6$ and 5 are also mentioned. Some kind of markings are usually made on the top of the bread, either a pattern of indenta. 
tions or the shape of a cross is made. In two cases, the indentations are identified as the "eyes" of the bread.

$K^{\prime} o l$ is the soup or broth made from crumbs of the sacred bread, parts of the sacrificed fowl and other ingredients. Once again, this is not secular cookery, but prepared only on ceremonial occasions. $K^{\prime} \circ l$ is not mentioned specifically in all accounts, but there is usually reference to some soup-like substance set on the mesa as an offering.

Finally, cigarettes are frequently mentioned as being used ceremonially. Today, factory made cigarettes have replaced the tobacco rolled in corn husks mentioned in the earlier accounts without any apparent change in the significance of the offering.

\section{Dissimilarites in the Ceremonies}

Perhaps the most obvious differences between the various agricultural ceremonies are the chants themselves. In none of the descriptions in the literature are the chants so long and complex as in Becanchen. In Socotz in the 1920's (Thompson, J. E. S., 1931: $115-118)$ the chant for a ceremony similar to the Wahil Kol contained only about six lines. In Quintana Roo, Villa Rojas (1945: 159) recorded a chant of only 15 lines.

There are also great differences in the personages addressed in the chants. In Becanchen, thirteen distinct non-Christian deities were addressed in the chants along with the more generic terms yumtsilob, meyahob, hoya'ob and tepalob (see pp. 290-293). In addition, over 20 saints, male and female, were addressed. Nowhere near this number were mentioned in any of the chants recorded in the literature.

In some of the references, there is a period of waiting after an incantation so that the gods may partake of the offerings on the mesa before the food is distributed to those present. In Becanchen, there was no such period of waiting.

Many of the accounts mention a chant uttered by the men during the consecration of the fowl with balche'. This was not done in Becanchen.

Another point of variation is the location of the ceremonies. Only the U Hanli Kol ceremony of Chan Kom and the Wahil Kol of Becanchen were performed in the yard of the house. All the others were performed in the field. Peraza, my informant, told me that the Wahil $\mathrm{Kol}$ used to be performed in the field, but it was difficult to verify this statement. 
There is also variation in who participates in the ceremonies. In a primicias ceremony described by Thompson (1931:115-117) only the milpero and men attended. In most of the ceremonies a group of family and friends attend, such as did in Becanchen. The rain ceremonies, usually called Chá Chaak are generally attended by the entire village. In one case, at a special rain ceremony in Quintana Roo known as the Okotbatam, several villages joined together in one ceremony (Villa Rojas 1945:115).

Timing and periodicity of the ceremonies are points of great variation. Of all the ceremonies described, the one most similar to the Wahil Kol of Becanchen was the U Hanli Kol of Chan Kom, yet the $U$ Hanli $\mathrm{Kol}$ was performed in August, September and October, and the Wahil $\mathrm{Kol}$ was being performed in April. A milpero performed $U$ Hanli $\mathrm{Kol}$ only when virgin forest was cleared, about every four years. In Becanchen the Wahil Kol could be performed any year the milpero desired.

$C h^{\prime} a$. Chaak ceremonies were generally held after planting, before the rains, but in Becanchen it was held in July or August, during the rainy season. And in Quintana Roo, in 1933, a large rain ceremony was held in October.

An interesting element of the Wahil Kol ceremony of Becanchen was the making of a wech, or armadillo, by wrapping balls of dough in leaf strips to make a shape similar to the said animal. The wech was baked along with the other sacred breads and placed on the mesa for the third and fourth chants. At the end of the ceremony, the wech was eaten along with the other foods. Nowhere in the literature is any mention made of the preparation of any effigy animal. Unfortunately, I did not inquire as to the significance of this animal offering and can offer no explanation at this time. With all the offerings on the mesa being so consistent with descriptions in the references, it is quite surprising to find such a noticeable variant.

\section{E. Change in Ceremonies Over Time}

Culture change over time has always been a topic of anthropological study. Having found descriptions of Yucatec agricultural ceremonies dating back to the middle 1800 's, it would seem there would be material here for analysis of changes the ceremonies have undergone. Actually, I have not been able to identify any progressions or patterns which could be called consistent. 
In Chan Kom in the 1930's, the arrangement of the mesa is more complex than in Becanchen in 1978, which might indicate a change over time in the direction of simplicity, but the chants used in modern day Becanchen are much more complex than those used in Chan Kom in the 30 's.

In Socotz, British Honduras, in the 1920's Thompson (1930:109) observed "the Hmen of the present time have degenerated into little more than herbalists." This is certainly not true of the men of Becanchen who is not an herbalist at all but is the leader of complex, important agricultural ceremonies.

In several instances, mention is made of a short chant uttered before slaughtering the fowl to be cooked for the ceremony. In Becanchen no such chant was performed. But again I do not feel there is enough evidence to indicate a pattern of change.

Robert Redfield had a chance to observe change in the village of Chan Kom. He revisited the town in 1948, seventeen years after his initial ethnographic study there. Although he did not make detailed observations of agricultural ceremonies during this more recent visit, his general impression was that little had changed as regards the observance of these rituals. The $U$ Hanli $\mathrm{Kol}$ had been made many times in recent years. Redfield $(1950: 115)$ concluded "the evidence indicates that the entire 'pagan' part of the traditional ways of life is maintained with unabated devotion."

As regards culture change in Becanchen, perhaps the most striking element of the Wahil Kol ceremony is just how unchanged are the offerings presented to the gods, compared to the offerings described in the literature. Except for the change from corn husk cigarettes to modern factory made cigarettes, and from a mesa made of bound sticks to a modern table, the use of the mesa, balche', saka?, the maize cakes, the soup and the cigarettes has remained consistent through time.

In the aspects of the ceremonies that do show variation, no pattern is apparent. I am inclined to believe that variation in the ceremonies depends upon the individual men. Redfield (1934:137) gives evidence to support this idea. He states "conspicuous variations [in the U Hanli Kol ceremony] appear from a comparison of the ceremony as performed by one h-men with its performance by another." The men directs every part of the proceedings from the location of the fire pit to preparations of the offerings. He alone knows the words of the incantations. Don Ramón, the men of Becanchen, had little or no contact with other working menob, so that individual 
traits or preferences in the running of the ceremony would remain in his village and immediate area, not merging or blending with the practices of neighboring menob.

But this, of course, does not explain why certain aspects of the ceremony are so consistent. It is an interesting question that could perhaps be answered if more information were available.

\section{Part. III. Suggested Guidelines for Future Ethnographies}

As has been stated in the previous section, no pattern of change emerges from the examples of agricultural ceremonies cited in this paper and there is no answer to the question why are some parts of the ceremonies so consistent while others show great variation. This is due, to a great extent, to the inadequacies of many of the ethnographic descriptions presented in the past. These questions can be addressed, I feel, if future ethnographers follow certain guidelines and strive to meet certain objectives.

\section{A. Ceremonial Cycle}

First of all, the ceremonial cycle for the entire year should be presented, if not from direct observation, at least from informants' information. A major weakness of this paper is that I was in Becanchen for only three months, February through April. To my knowledge, the Wahil Kol ceremony was the only agricultural ceremony being performed during those months. Among the X-Cacal Maya of Quintaria Roo (Villa Rojas 1945:116-117), the $U$ Hanli $\mathrm{Kol}$ ceremony was generally held in February, although sometimes as late as May. Because Villa Rojas recorded the cycle of ceremonies for an entire year, he was able to determine that the $U$ Hanli Kol was a ceremony of thanksgiving relating back to the previous year's harvest. Since recording the Wahil Kol ceremony of Becanchen, I have been somewhat perplexed by the offering of first fruits during a time of burning and planting. Perhaps, as in Quintana Roo, they were offering the fruits from the previous year's harvest. A more thorough investigation on my part would have clarified this point.

Thompson (1930:117) and Redfield and Villa Rojas (1934:143. 4) described agricultural ceremonies that were performed at the time the first ears of corn were ripening. Once again, due to the 
brevity of my stay in Becanchen, I am unable to report the ocurrence of a comparable event in that town. Material that would be useful in comparative analysis was simply not obtained.

\section{B. Physical Description}

A detailed physical description of the ceremony should be presented by the ethnographer to facilitate comparisons. Most of the analysis presented in Part II of this paper was made possible because four or five earlier ethnographers did a good job in describing the physical aspects of various ceremonies. The arrangement of the mesa and the preparations of the offerings were described in enough detail to bring out the remarkably consistent character of the offering. Less acute observations would not have distinguished the ceremonial drink saka' from the drink posole, a secular, every-day drink, or the $k^{\prime}$ ol from ordinary soup. More of these descriptions in the future will confirm or refute the notion that certain aspects of the ceremony are firmly fixed while much variation is allowed in others.

\section{Questioning Informants}

One of the weaker points of this paper is that I missed many opportunities to ask my informant, a close friend of the men, the meaning of several aspects of the ceremony. The wech, or armadillo, is an obvious example. I have found no clue whatsoever regarding the reason for preparing this effigy animal and including it with the other offerings on the mesa.

The list of deities which I have extracted from the text of the chants would have provided excellent material for questioning. Just who are the yumtsilob? How do they differ from the meyahob or the tepalob? What does yum kuch do? Future ethnographers should ask questions such as these.

One should keep in mind, of course, the pitfalls of ethnographic enquiry. In my own case, I could not converse directly with the men, Don Ramón, because he spoke very little Spanish and I spoke very little Maya. I had to work through an intermediary, Don Eduardo, who in many cases, I felt, injected his own ideas into the situation to such an extent that the issue became confused. Ideally, the ethnographer of the future should be a fluent Maya speaker. 


\section{Life History of the Men}

In order to address the question of why certain aspects of the ceremonies are so constant while others show great variation, it would probably be useful to inquire of the men just how he became a men. From whom did he learn his craft? When he was learning the ceremonies, was he instructed that certain points were crucial and should not be altered? Was he told he was free to exercise individuality on other points?

Learning the life history of the men could be useful in another respect. If many more studies of Maya agricultural ceremonies are done, it seems likely to me that regional characteristics will emerge. At this time there are simply not enough examples published to allow one to say there are certain variants peculiar to Quintana Roo as opposed to northern Yucatán for example. And there are no examples from Campeche, the State directly to the west. If regional differences do become apparent with increased information, it would make for interesting comparisons. Then, if a men of one area is found conducting his ceremonies in a manner identified with another area, instead of confusing the issue, it might be learned through inquiry into his life history that originally he was from tha other area, or perhaps his teacher was from the other area.

\section{E. Transcription and Translation of Chants}

One of the strong points of this paper, I believe, is the presenta. tion of an accurate transcription and (hopefully) an accurate trans lation of the men's incantations. I think the meaning of the ceremony can really only be understood by studying these prayers or chants. In the case of the Wahil Kol presented in this paper, a close reading of the chants reveals the central theme. Spoken repeatedly, that theme is "I offer to you, the various deities, these holy offerings, in exchange for protection for Luis Xool and his family."

Without the chants being transcribed, certain ceremonies could easily be confused with others because the physical aspects of the ceremonies are so similar. Ceremonies of thanksgiving could be confused with rain ceremonies.

To my mind, the most exciting results from transcribing the chants are the revelations of the names of the deities addressed. Here we are given a look into the distant past. The deities mentioned are 
so distinct from anything introduced by the Spanish that we are surely seeing pre-Columbian survivals.

It would not be going too far to assert that here we may even find clues useful in the on-going research into decipherment of the ancient Maya hieroglyphic writing. One example is that the depiction of a jaguar paw often is associated with titles of rulers on the Classic Maya monuments. In the chants presented in this paper we find the names of two deities, $t^{\prime} u p k^{\prime} a b$ balam and $t^{\prime} \circ x k^{\prime} a b$ balam, both referring to the "hand of the jaguar."

Going all the way back to Olmec times, a thousand years before Christ, there is an iconographic constant of an important personage, ruler or deity, shown with his right hand raised in the air. In Becanchen, three thousand years later, when Luis Xool made the promesa over the mesa at the end of the Wahil Kol ceremony, he made his pledge to none other than Noh $a h k^{\prime} a b$, the great right hand.

In the ethnographies in the past, not enough attention has been paid to the actual words of the chants and in many cases incorrect translations have been made. Future ethnographers should certainly devote their efforts toward this aspect of the ceremonies.

\section{Conclusion}

The Wahil Kol ceremony of Becanchen is one example in a long tradition of similar ceremonies performed in the Yucatán Peninsula. The main elements of the ceremony are as follows: the men who conducts the event, the mesa with its accompanying cross or crosses, candles, incense, offerings of balche', saka', maize cakes, $k^{\prime} o l$ and cigarettes. While these elements have remained relatively constant over time, there is a great deal of variation in the chants, the location of the ceremony, who participates, and the timing and periodicity of the ceremony. Within this range of variation, no progression or pattern of change is apparent. Variety probably results from the peculiarities of individual menob.

Ethnographers of the future could facilitate better comparative analyses of these ceremonies if they describe the ceremonial cycle for an entire year, include a detailed physical description of the ceremony itself, ask detailed questions of their informants, learn the life history of the presiding men, and include accurate transcriptions and translations of the chants. 
There is today, in the Yucatán Peninsula, an excellent opportunity for anthropologists to records native ritual events which are survivals from the distant past. Although these ceremonies will not disappear in the immediate future, surely urbanization and modernization will diminish their number and bring about changes. Let us hope many more of these events will soon be recorded to forever preserve this rich and meaningful part of Maya culture.

\section{REFERENCES}

Barrera Vásquez, Alfredo

1976 El folk-lore de Yucatán (Spanish translation by Brinton 1883 with notes), Mérida

Blatr, Robert W. and Vermon-Salas, Refugio

1965 Spoken (Yucatec) Maya, University of Chicago.

Brinton, Daniel G.

1883 "The folk-lore of Yucatán". The folk-lore Journal, Vol. 1, London.

Diccionario Maya Cordemex

1980 México.

GanN, Thomas W. F.

1918 "The Maya Indians of southern Yucatan and northern British

Honduras". Bureau of American Ethnology, Bul. 64, Washington.

Motul Dictionary

1929 Diccionario de Motul, maya-español, atribuido a Fray Antonio de Ciudad Real y Arte de lengua maya, por Fray Juan Co ronel, J. Martínez Hernández, ed., Mérida.

Pagheco Gruz, Santiago

Peraza

1947 Usos, costumbres, religión, supersticiones de los mayas, Mérida.

1978 Don Eduardo Peraza Castillo, personal communication, Becanchen.

Pérez Dictionary

1866-77 Diccionario de la lengua maya (Compiled by J. Pío Pérez; completed by C. H. Berendt), Mérida.

REDFIELD, ROBERT

1950 A Village that Chose Progress, Chan Kom Revisited, Chicago.

Redield, Robert and Villa Rojas, Alfonso

1934 Chan Kom, a Maya Village. Carnegie Institute of Washington,

Roys, RALPH L. Pub. 448, Washington.

1965 Ritual of the Bacabs: A Book of Maya Incantations. (Translator and editor), Norman.

STEGgerda, MORRIS

1941 Maya Indians of Yucatan. Carnegie Institute of Washington, Pub. 531, Washington.

THOMPSON, EDWARD H.

1932 People of the Serpent, Life and Adventure among the Mayas, Cambridge.

Thompson, J. ERIG S. 
1931 "Ethnology of the Mayas southern and central British Honduras", Field Museum of Natural History, Anthropological Series, Vol. 17, No. 2, Chicago.

1934 Sky Bearers, Colors and Directions in Maya and Mexican Religion. Carnegie Institute of Washington, Pub. 436. ContribuTOzzer, AlFRed M. tions to American Archaeology, Vol. 2, No. 10, Washington.

1907 A Comparative Study of the Mayas and the Lacandones. New York.

1941 Landa's Relación de las cosas de Yucatán, A translation, edited with notes. "Papers of the Peabody Museum of American Archaeology and Ethnology." Vol. 18, Cambridge.

Villa Rojas, ALfonso

1945 The Maya of East Central Quintana Roo. Carnegie Institute of Washington, Pub. 559, Washington.

\section{Postcript}

When I returned to Becanchen for a brief visit in 1980, the men, Don Ramon Balam Camara, was ailing. In his own words, he was dying. Being too sick to work, he had performed no Wahil Kol ceremonies for some months and I was told there would be no Ch'a Chaak ceremony in Becanchen that year. Don Ramon had no student, or apprentices at the time I talked to him in 1978. I do not know if he has recently acquired any, but I think not. Becanchen, in 1980, was without a working men. Whether any were hired from outside the town to come to perform there, I do not know. I do know that in a rancheria, a very small settlement, quite close to Becanchen, a Wahil Kol ceremony was being planned to take place in July, 1980.

Appendix $A$

Non Christian Deities Mentioned in the Chants

Yumtsilob "lords"

"This is a collective term, probably including all the deities mentioned below.

T'up k'ab balam "littlest hand jaguar"

Gann $(1918: 47)$ recorded the prayer of a men in which he called to "chanttupchac". In Socotz, Thompson, J. E. S. (1930:107) 
observed that the "yumil Qašob" (lords of the forest) were under the orders of "A T'up" which he translated "last born." In Chan Kom (Redfield and Villa Rojas 1934-114), the "thup" was considered to be the most important of the balams, the balam that resided in the east. Of the various chaaks, " $x$-thup-chaac". made rain fall in abundance. In a chant in the $U$ Hanli Kol ceremony in Chan Kom, "tuppil-caan-chaac" (littlest-sky-chaak) is addressed (Redfield and Villa Rojas 1934:345).

T'ox k'ab balam "pour or distribute hand jaguar"

In Quintana Roo, Villa Rojas (1945:102) wrote "Ah-thoxoncaan-chaac" (distributor-sky-chaac) produced fine persistent rain and was referred to in the prayer of the Okotbatam ceremony (1945:159). Peraza, my informant, translated this as the "hand of the tiger that distributes".

Nohoch balam "great or large jaguar"

Kalan kolob "guardian milpa"

Kalan $x u$ 'uk'ob "guardian boundary stones"

According to Peraza, piles of stones were used in the past to mark the corners of the milpa.

Kalan misob "guardian sweeping"

In Quintana Roo (Villa Rojas 1945:102) one of the chaaks was known as "Mizen-caan-chaac (sweeper-sky-chaac)". He cleaned the sky after a rainfall.

Hil p'isib che" "drag along measure pole"

My informant called him "a lesser god who measures the forest." Measuring sticks are still used today to mark out the boundaries of a milpa. They are four "brazos" long, about 20 feet.

$K^{\prime} e n$ ke'eles ik'ob "twist fright winds"

My informant translated this simply as "evil winds".

T'ul pach ik'ob "place behind or back winds".

Peraza translated this as winds that follow a person. 
Moson ikob "whirlwinds"

These are the most frequently mentioned winds in the literature. They are closely associated with the winds that help in burning the milpa known as "kakal mozonikob", "fiery whirlwinds" (Villa Rojas 1945:123) Redfield and Villa Rojas (1934:164-168) write that almost all winds are potentially evil, causing disease. The "mozon $i k$ 'ob" are the small whirlwinds known as "dust devils" in the United States.

Meyahob "workers"

In the chant recorded by Gann $(1918: 47)$ the men called to "meyanaheex".

Hoya'ob "waterers or sprinklers"

In Quintana Roo, Villa Rojas (1945:102) observed that the "ah-hoyas (sprinklers) occupied first place in the devotion of the natives." Chaacs, he says, are also called "ah-hoyas." In the Ch'a Chaac ceremony recorded in Chan Kom (Redfield and Villa Rojas 1934:352), the men called to the "chaacilob" and "ahhoyabilob."

Tepalob "powerful ones"

(Ah) tepal is defined as "el poderoso" in the Diccionario Maya Cordemex (1980:786). Gann (1918:46) recorded the men chanting "Cin kubic ti atepalob" while scattering $s a k a$ " to the world directions. Villa Rojas (1945:160) recorded a prayer in which the men called out to "noh Ah-tepalob" and translated it as "the great rulers." Redfield and Villa Rojas' (1934:344) informant told them the ah tepalob watched over the old pueblos, like Chichen Itza.

Nukuch ak'ab xuxubobo "great night spirit-that-whistles"

Xuxub is "whistle" in the Pérez Dictionary (1866-77:401). In Chan Kom (Redfield and Villa Rojas 1934:113) they say when a whistling sound is heard in the forest at night, it is thought to indicate the presence of the balamob. 
Noh ah k'ab "great masc. prefix hand"

This is not mentioned in all the chants, but at the very end, when Luis Xool is making his promesa, he directs it to noh ah $k^{\prime} a b$. In Chan Kom (Redfield and Villa Rojas 1934:347), the men chants "in kubic tu noh u kab ca yumil ti dios," translated "I offer it to the right hand of our Lord God."

\section{Yum kuch "father burden-bearer"}

Yum kuch is mentioned only in the second and third chant. My informant translated it as "cargador". Barrera Vásquez (Diccionario Maya Cordemex 1980:343) defines (Ah) kuch as "los hermanos menores que soportan la carga de la tierra."

\section{Appendix $B$}

Free Translation of the Second, Third and Fourth Chants

\section{Second Chant}

59. In the holy name of god the father, god the son, god of the holy spirit. 60 . I stand, I pray to the beautiful father god the father, god the son, god the holy spirit. 61. I pray to the workers, the waterers, the powerful ones. They come. They set in order the virgin mesa. 62. I stand. I make an offering of the virgin cigarettes, the virgin wine, and the virgin drink. 63. They come with pleasure. They set in order the holy virgin drink. I stand. I receive them. 64. ? 65. I make an offering of the harvest from seventy mecates. 66. I stand. I make an offering of national forest. They come. They set in order. 67. I stand. I make an offering of the holy virgin first fruits in the town of Becanchen for protection over Luis Xool. 68. For protection over his family and protection over his children. 69. I stand. I make an offering. They come with pleasure. They set in order the great mesa of god the father, god the holy spirit. 70. I stand, I call to the guardians of the milpas, guardians of the boundary stones, guardians of the sweeping. To he who measures the forest, to the evil winds, the winds that follow, the whirlwinds. 71. I stand, I make an offering of the holy virgin drink to the lords on the great mesa. 72. The virgin cups are lined up on the virgin mesa. 73. I call out to them. They move in the south, in the west, 
in the north. 74. In the east. I stand, I receive littlest hand of the jaguar, the hand of the jaguar that pours, and the great jaguar on the virgin mesa, 75. On the virgin mesa of god the father god the holy spirit. 76. I call to them on this virgin Thursday. I stand, I receive them. 77. Here on this virgin Thursday. 78. They move in the four corners of the sky, in the four corners of the land. 79. I stand, I receive the lords. They come with pleasure. They set in order in the name of god the father, god the holy spirit. 80. Glory to the father. Glory to the son. Glory to the holy spirit. 81. I stand, I make an offering, I lower the holy virgin drink on the great mesa to the lords. 82 . They come with pleasure. They set in order the great: mesa of god the father, god of the holy spirit. 83. Placed in corners, divided into parts, swept, washed, cleansed is the virgin mesa of god. I call out to them. They come with pleasure to the virgin mesa. 84. They move in the four corners of the sky, in the four corners of the land. 85. I stand, I receive them. I make an of iering of the holy virgin first fruits for protection over the burden bearer. 86. Over his work in the great forest, in the great planting lands. 87. To the beautiful father god. For protection over his work. 88 Where you(?) do penance, where you(?) live. I make an offering. They come with pleasure. They set in order in the name of god the father, god the son, god the holy spirit. 89. Glory to the father. Glory to the son. Glory of the holy spirit.

90. Placed in corners, divided into parts, swept, washed, cleansed is the virgin mesa of god the father, god the holy spirit. 91. They come with pleasure, beautiful virgin of riches, beautiful virgin of the fountain. 92. I call out to the beautiful virgin of the three persons, to the beautiful virgin of riches, to the beautiful virgin lady of stones. 93. I pray to the beautiful virgin Santa Ana, Santa Lucía, perfect solace. 94. To the beautiful virgin of the saved, to the beautiful virgin of the Assumption, to the beautiful virgin of Fátima, beautiful virgin of Guadalupe. 94. To the beautiful virgin Santa María. 95. I call out to the beautiful virgin Marta. They move with the workers, the waterers, the powerful ones. 96. I call out on the virgin mesa of god the father, god the holy spirit. 97. I stand, I make an offering of the holy virgin first fruits. I pray to Señor San Juan Bautista, San Pedro, San Isidro, holy cross, of Baxak', to Señor San 'Antonio, Señor San José, San Joaquín. 98. San Felipe, Señor San Lorenzo, San Buenaventura, San Francisco and San Dimas. 99. To the holy three kings of Tizimin San Ro- 
mani Campeche, Señor Santiago of Halach'o to father Santiago. 100. I make an offering to beautiful father god. They move. To Señor San Bernardino, I call out. 101. I call out to the workers, the waterers, the powerful ones on the virgin mesa of god, the father. 102. On the virgin mesa of god the holy spirit. 103. In the name of god the father, god the son, god of the holy spirit. 104. I lower the holy virgin drink. I lower it to the four corners of the sky, to the four corners of the land. 105. I lower it to the north, to the south. 106. I lower it to the north. 107. I lower it to the west. 108. I lower it to the east. 109. To the beautiful father god, beautiful virgin Santa María. I make an offering. They come with pleasure, they set in order. 110. In the name of god the father, god the son, god of the holy spirit. 111. Glory to the father. Glory to the son. Glory of the holy spirit. Amen.

(At the end of this chant, saka' is distributed to the participants).

\section{Third Chant}

112. In the holy name of god the father, god the son, god of the holy spirit. 113. I stand. I pray to the beautiful father god the father, god the son, god of the holy spirit. 114. Here I stand. I call out on the virgin mesa to the lords. They come with pleasure. They set in order the virgin mesa. 115. The virgin bowls are lined up. They come with pleasure. They set in order the four corners of the mesa of god the father, the four corners of the mesa of god the holy spirit. 116. Here I stand. I receive them. They move in the four corners of the sky, on the four corners of the land...117. They come with pleasure. I pray to them. I make an offering of the holy virgin first fruits. 118. I stand, I receive them. They come with pleasure. 119. They come with pleasure. I receive them. I make an offering of the virgin cigarettes, the virgin wine, the virgin fruit, and the great bread. 120. I make an offering of the virgin fowl(?) on the great mesa to the beautiful father god the father, god the son, god of the holy spirit. 121. I stand, I pray to them. I move them in the south, in the west, in the north. 122. I stand. I receive them in the east, father littlest hand of the jaguar, the hand of the jaguar that pours, the great jaguar. 123. They come with pleasure. They set in order. The workers, the waterers, the powerful ones. 124. I stand, I call to them. They move. I stand. I make an offering of this holy virgin work. 125 . I pray to them. 
The guardians of the milpa, the guardians of the boundary stones; the guardians of the sweeping, he who measures the forest, the evil winds, the winds that follow, the whirlwinds. 126. I stand. I receive them on the virgin mesa of god the father. 127. God the son, god of the holy spirit. 128. They come with pleasure. They set in order. I pray to them on the virgin mesa of god. 129. I make an offering of these holy virgin first fruits, these seventy mecates. 130. I stand. I make an offering of seventy mecates of national forest. 131. For protection over Luis Xool. 132. I stand. I make and offering in the great mesa of beautiful father god. 133. For protection over his family and over his children. I stand. I make an offering on the great mesa of god. 134. I make an offering of the holy virgin first fruits. I make an offering to the great right hand of the beautiful god. 135. They come with the workers, the waterers, the powerful ones. 136. I stand. I receive them on the great mesa. Father littlest hand of the jaguar, the hand of the jaguar that pours, the great jaguar. 137. I make an offering on this virgin Thursday, at this virgin three in the afternoon. 138. I make offering on the virgin mesa, at the virgin three in the afternoon, on the virgin Thursday. 139. I ask the beautiful father god for license. I make an offering of this service. 140. To the great right hand, to the littlest hand of the jaguar, to the hand of the jaguar that pours, to the great jaguar. 141. I call out to them. 142. Here on the virgin mesa of god the father, god of the holy spirit. 143. I stand. I make an offering of the holy virgin drink lined up in the four corners of the mesa of god the father. 144. The four corners of the mesa of god of the holy spirit. 145. They come with pleasure. They set in order the great mesa. I call out to them. 146. Here on the great mesa of the beautiful father god, I make an offering of these holy virgin first fruits in the town of Becanchen. 147. I make an offering of these holy virgin first fruits for protection over father burden-bearer. 148. Father burden-bearer, his work in the great forest, in the great planting land. I make an offering to the beautiful god the father, god the son, god of the holy spirit. 149. Here I make an offering of the holy virgin first fruits to the great right hand of the beautiful father god the father, god the son, god of the holy spirit. 150. Glory to the father. Glory to the son. Glory of the holy spirit.

151. Placed in corners, divided into parts, swept, washed, cleansed is the virgin mesa of god the father, god of the holy spirit. 152 . 
They come with pleasure, beautiful virgin of riches, beautiful virgin of the fountain, 153. Here I call out to the virgin mesa of god the father, god of the holy spirit. 154. Here I pray to the beautiful virgin everlasting. 155. I call out to the beautiful virgin. 156. Guadalupe. They come with pleasure. They set in order the virgin mesa of god the father, god of the holy spirit. 157. I pray to the beautiful virgin Santa Ana, Santa Lucía, perfect solace, to beautiful virgin of the saved, to the beautiful virgin of the Assumption, to the beatutiful virgin of Fátima. 158. To the beautiful virgin of Guadalupe, to the beautiful virgin Santa María. 159. Here I call to the beautiful virgin Marta. 160. They move with the workers, the waterers, the powerful ones. 161. Here I call out on the virgin mesa of god the father, god the holy spirit. 162. I stand. I receive them on the mesa of the beautiful father god. Señor San Juan Bautista, San Pedro, San Isidro, holy cross of Baxak', Señor San Antonio, Señor San José, San Joaquín, San Felipe. 163. Señor San Lorenzo, San Buenaventura, San Francisco and San Dimas. 164. To Señor holy three kings of Tizimin, San Romani Campeche, Señor Santiago Halach'o, holy Christ of Chumayel, Señor San Miguel Archangel, children of Atocha, heart of Jesus. 165. I call out to Señor San Bernardino. They move. The workers, the waterers, the powerful ones. 166. I stand. I receive them on the virgin mesa of god the father, god the son, god of the holy spirit. 167. Glory to the father. Glory to the son. Glory of the holy spirit.

(At the end of this chant, no food or drink is distributed. The mesa is rearranged for the fourth chant.)

\section{Fourth Chant}

168. In the holy name of god the father, god the son, god of the holy spirit. 169. I stand. I pray in the name of the beautiful father god the father, god the son, god of the holy spirit. 170 . The lords come with pleasure. They set in order the virgin mesa. I receive them. 171. I stand. I make an offering of this holy virgin soup, virgin broth. 172. Of virgin fruit, virgin fowl(?), I make an offering of the virgin great bread. 173. I stand. I make an offering. They come with pleasure. They set in order the virgin mesa. 174. I call out to them. I move them in the four corners of the sky, the four corners of the land. 175. I stand. I receive them. I call 
out to the lords. They move. 176. I stand, I receive them. Father littlest hand of the jaguar, the hand of the jaguar that pours, the great jaguar. 177. They come with pleasure. They move in the four corners of the mesa of god the father, in the four corners of the mesa of god the holy spirit. 178. Here I stand. I make an offering of the holy virgin soup on the great mesa of the beautiful father god. 179. They come with pleasure. They set in order the virgin mesa. I stand. I receive them. 180. They move. The guardians of the milpa, the guardians of the boundary stones, the guardians of the sweeping, he who measures the forest, the winds, the winds that follow. 181. The whirlwinds. 182. I stand. I receive them. They come with pleasure. They set in order the virgin mesa. 183. I stand. I receive them. I make an offering of the holy virgin first fruits. 184. For protection over Luis Xool. 185. Over his family and over his children. 186. I make an offering to the great mesa, to the beautiful father god. I make an offering of the holy virgin first fruits for protection. 187. I make an offering to the great right hand, to father littlest hand of the jaguar, to the hand of the jaguar that pours, to the great jaguar. 188. They come. The workers, the waterers, the powerful ones. I stand. I receive them on the virgin mesa of god the father. 189. God the son, god of the holy spirit. 190. I call them in the morning(?). 191. On this virgin Thursday. I call out to them with the holy virgin wine. I stand. I receive them. 192. I stand. I receive them. I make an offering of these holy virgin first fruits. 193. I call out to them. They move in the four corners of the sky, in the four corners of the land. 194. The lords move in the four corners of the sky, in the four corners of the land. 195. They come. They set in order the four corners of the mesa of god the father. 196. The four corners of the mesa of god the holy spirit. 197. I stand. I make an offering in the afternoon on this virgin Thursday. I make an offering of these holy virgin first fruits. 198. I ask the beautiful father god for license. I purify(?). On the virgin mesa. 199. To the lords. 200. ?. In the afternoon on this virgin Thursday, 201. Virgin three in the afternoon. I stand. I purify(?) the virgin mesa of the beautiful father god. The workers, the waterers. 202. The powerful ones. 203. I stand. I make an offering of these holy virgin first fruits on the great mesa of god the father, god the son, god of the holy spirit. 204. I lower the holy virgin cigarettes for the great nocturnal whistling spirits, to the nocturnal watereres, the nocturnal powerful ones. 205. I lower 
them for the visit of the lords. I lower them in the name of god the father. 206. God the son, god of the holy spirit.

207. Placed in corners, divided into parts, swept, washed, cleansed is the virgin mesa of god the father, god the holy spirit. 208. I kneel with pleasure. I receive the beautiful virgin of riches, the beautiful virgin of the fountain. 209. They come with pleasure. The beautiful virgin of the three persons, the beautiful virgin lady of stone, the beautiful virgin everlasting. 210. Beautiful virgin Santa Ana, Santa Lucía, perfect solace, beautiful virgin of the saved, beautiful virgin of the Assumption. 211. To the beautiful virgin of Fátima, beautiful virgin of Guadalupe, beautiful virgin Santa María. 212. I kneel. I receive the beautiful virgin Marta. 213. They move. The workers, the waterers, the powerful ones. 214. They come with pleasure. The set in order the mesa of god the father. 215. God the holy spirit. 216. I stand, I make an offering. 217. I kneel at the great mesa of beautiful father god. 218. I pray to father San Juan Bautista, San Pedro, San Isidro. 219. To the holy cross of Baxak', Señor San Antonio, Señor San José, San Joaquín, San Felipc. 220. Señor San Lorenzo, San Buenaventura, San Francisco, and San Dimas. 221. To the holy three kings of Tizimin, San Romani Campeche, Señor Santiago of Halach'o, holy Christ of Chumayel, Señor San Miguel Archangel and child of Atocha. 222. Heart of Jesus, Señor San Martín. 223. I kneel, I do penance to Señor San Bernardino. They move. The workers, the waterers, the powerful ones. 224. I call out to them on the virgin mesa of god the father. 225. On the virgin mesa of god holy spirit. 226. I make an offering. I kneel. ?. Beautiful father god. 227. I ask for licence. I make an offering of the holy virgin first fruits. 228. I make an offering of this service on the great mesa of beautiful father god. 229. I purify(?) the virgin mesa. I ask for license on this virgin afternoon, on this virgin Thursday. 230. I make an offering at this virgin three in the afternoon on the great mesc of god the father. 231. God the son, god the holy spirit. 232. Glory to the father. Glory to the son. Glory of the holy spirit. Amen.

233. I lower the holy virgin soup. I make an offering on the great mesa of the beautiful father god. 234. They move. Father littlest hand of the jaguar, the hand of the jaguar that pours, the great jaguar. 235. They come, they set in order. I lower it to the four corners of the sky. 236. I lower it to the south. 237. I lower 
it to the north. 238. I lower it to the west. 239. I lower it to the east. 240. I make an offering to the beautiful virgin, to the beautiful father god, on the virgin mesa. 241. I lower the holy virgin soup in the name of god the father, god the son, god of the holy spirit.

(At this point, the men calls Luis Xool over to the mesa and says the following.)

242. I offer my pledge to the great right hand for protection. 243. In the holy name of god the father, god the son, god of the holy spirit.

(At this point, the chanting is completed. Food and drink is distributed to all present.) 


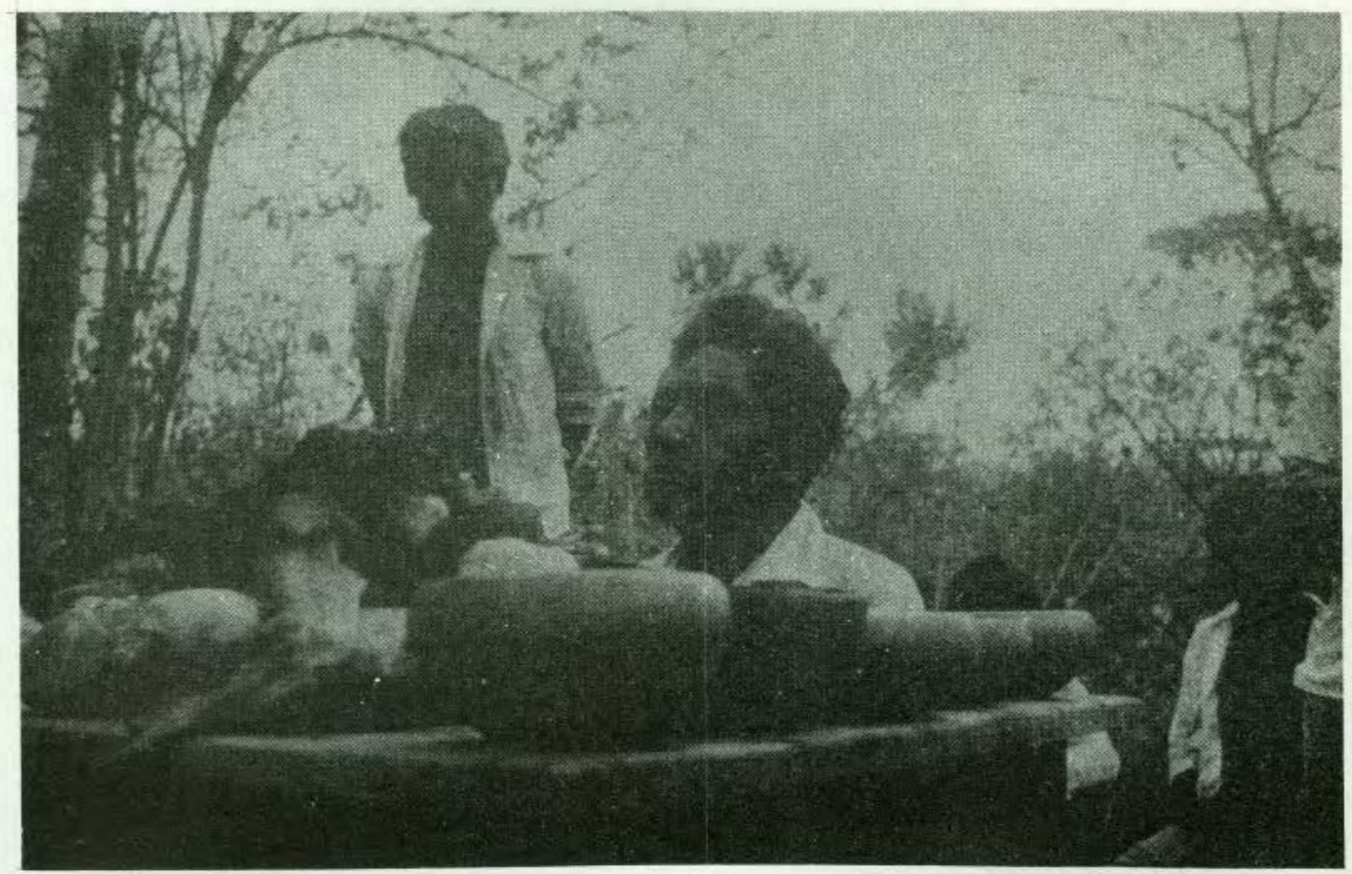

Don Ramón Balam kneels at the end of each chant.

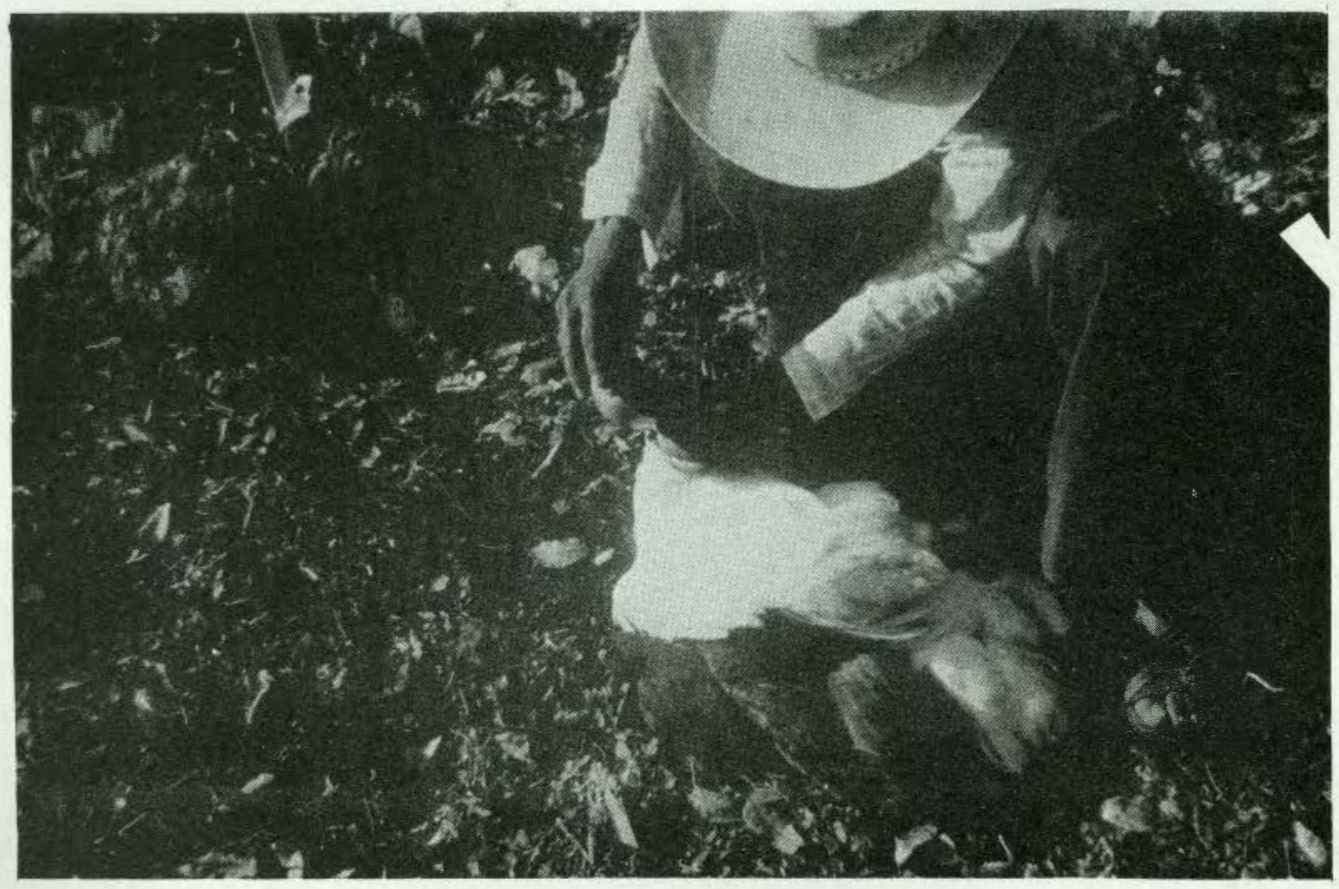

Pouring balche' down the throat of chicken to be slaughtered.

Estudios de Cultura Maya. Vol. XV, 1984

Instituto de Investigaciones Filológicas/

Centro de Estudios Mayas, UNAM 


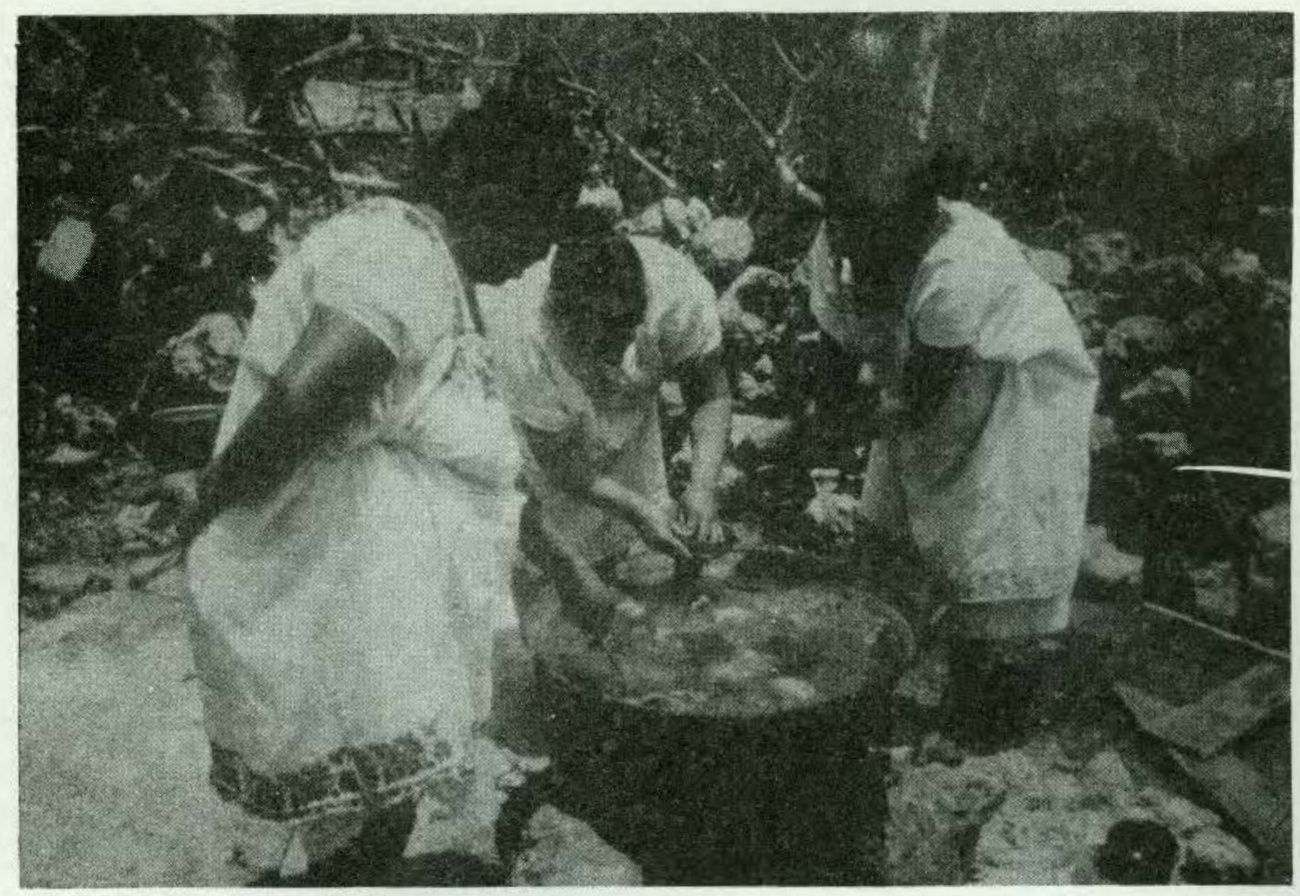

Making the sopa.

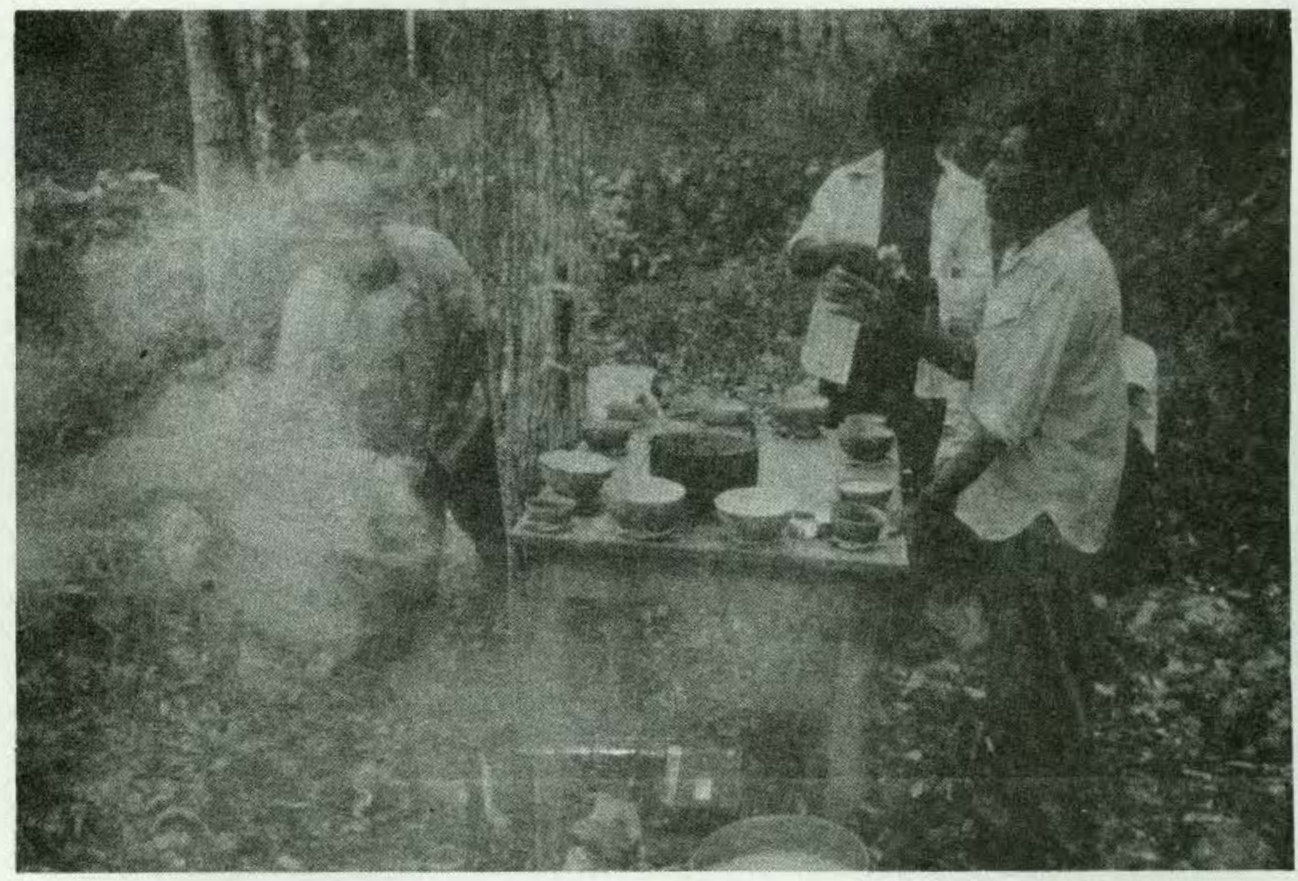

The second chant.

Estudios de Cultura Maya. Vol. XV, 1984

Instituto de Investigaciones Filológicas/

Centro de Estudios Mayas, UNAM 


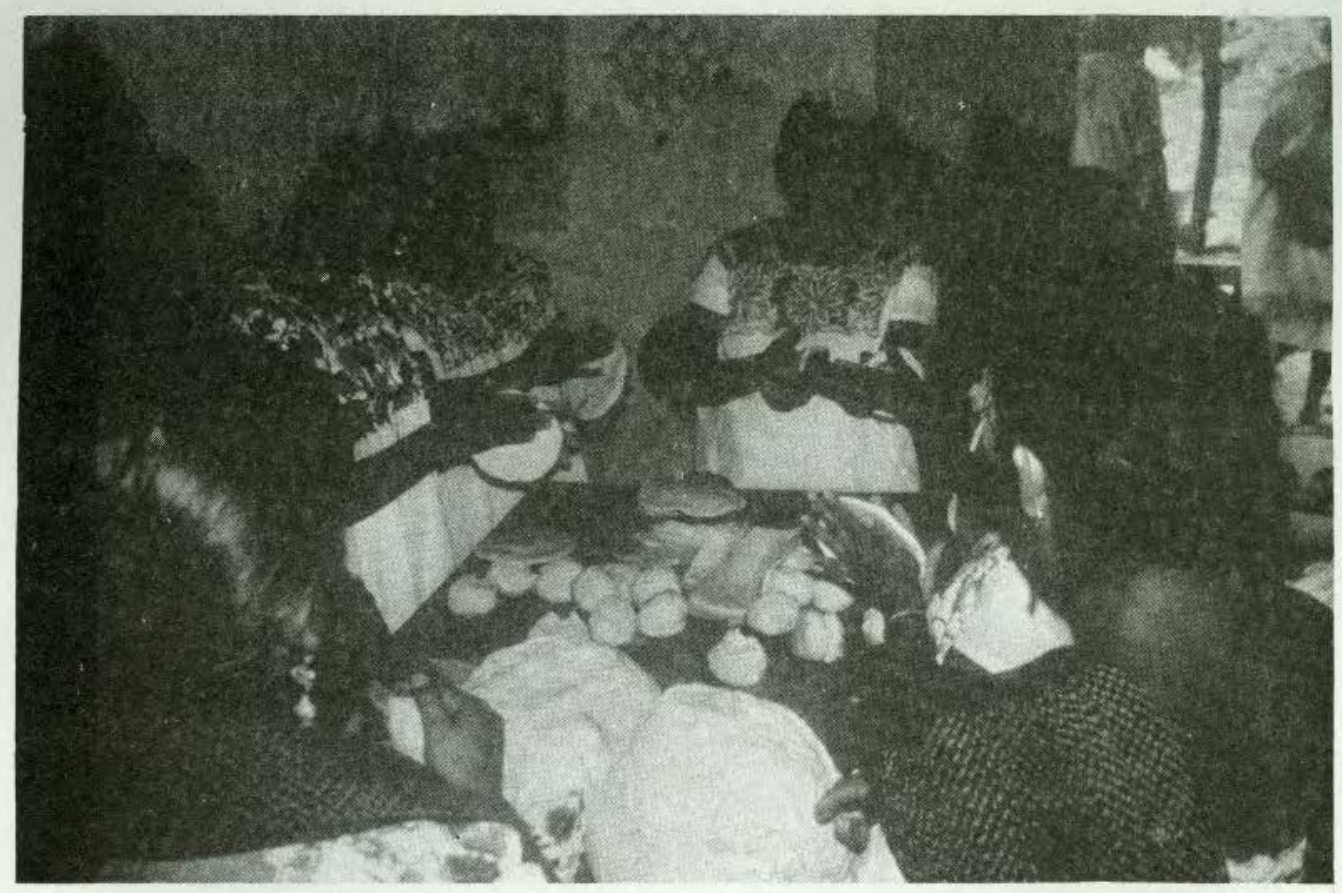

Women helping prepare the breads.

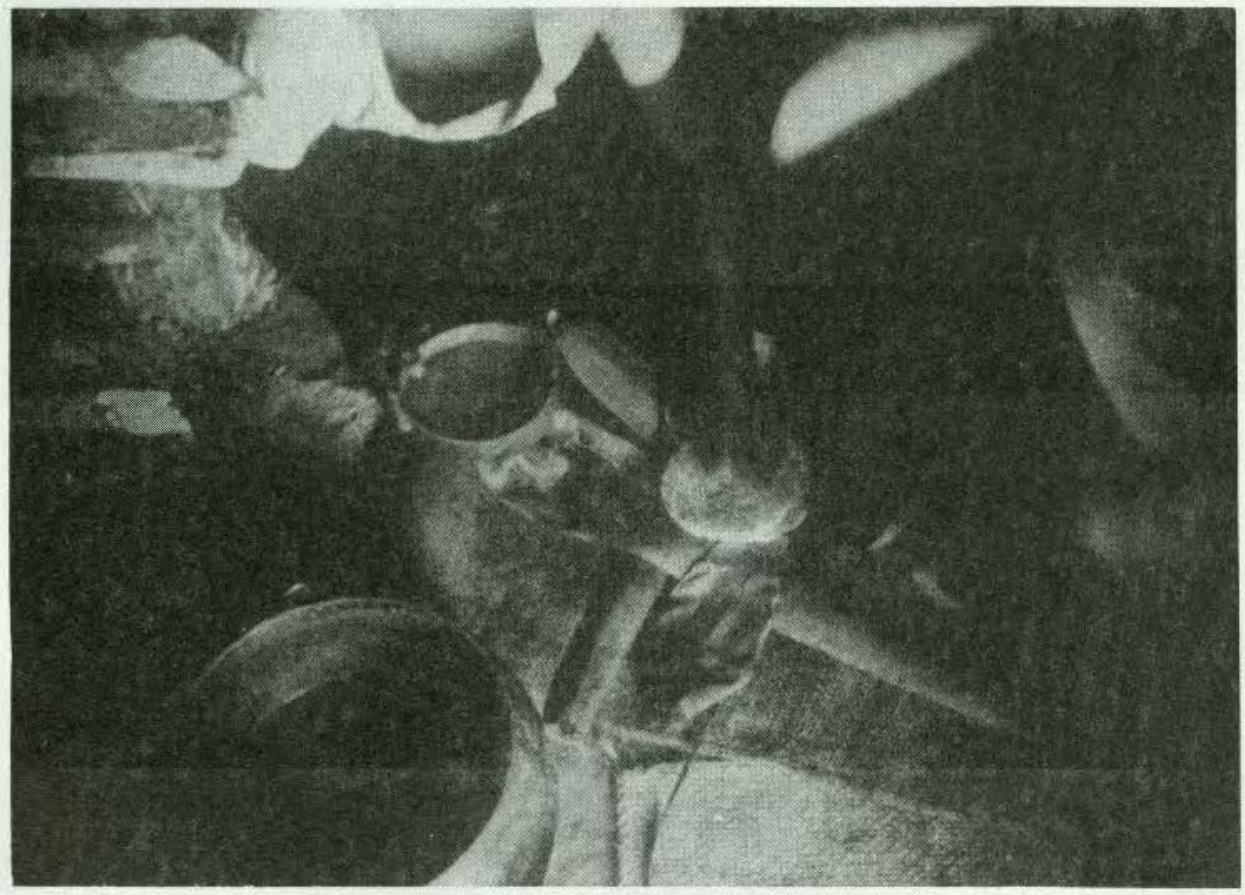

Spreading sikil on the sacred breads.

Estudios de Cultura Maya. Vol. XV, 1984

Instituto de Investigaciones Filológicas/

Centro de Estudios Mayas, UNAM 


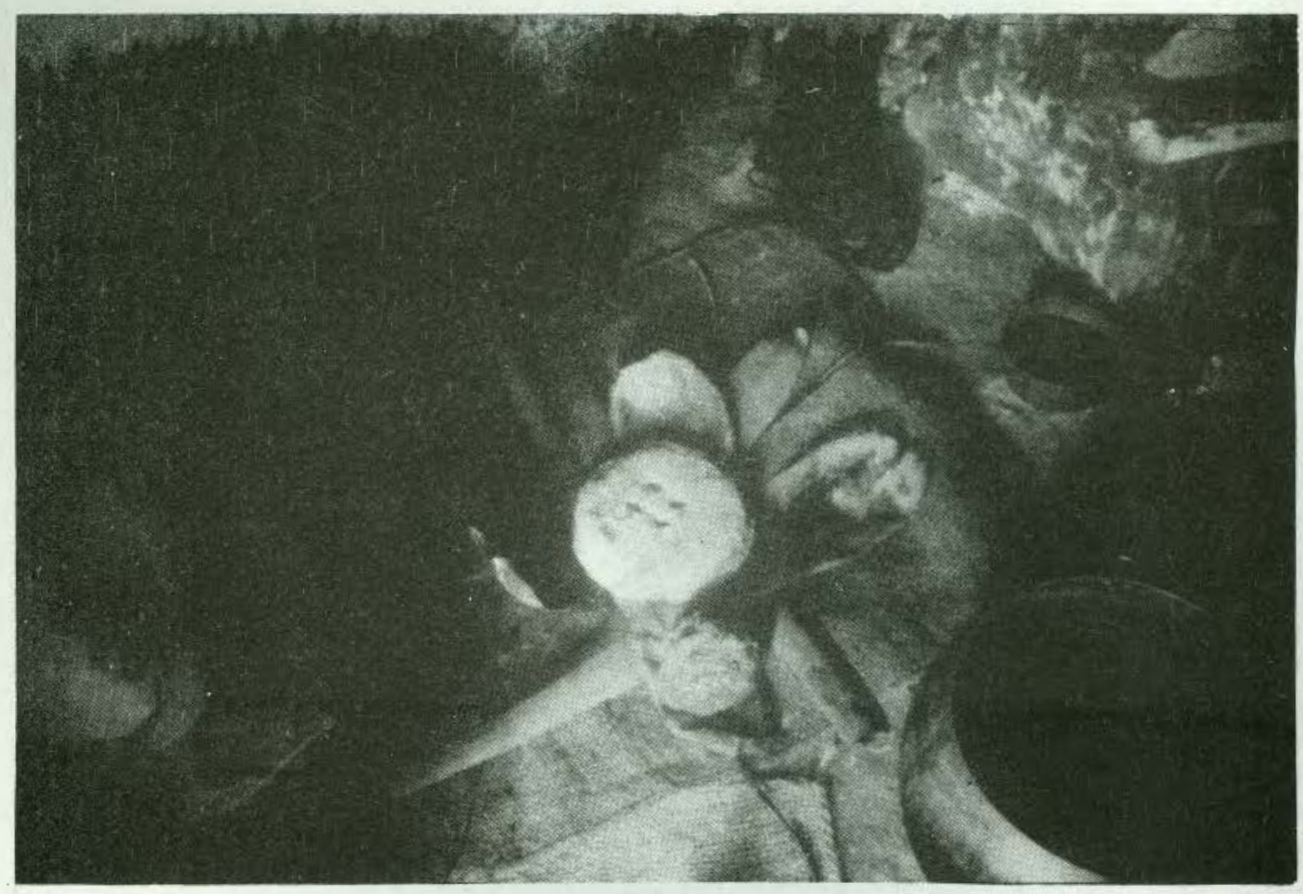

Making the sacred bread, with four eyes.

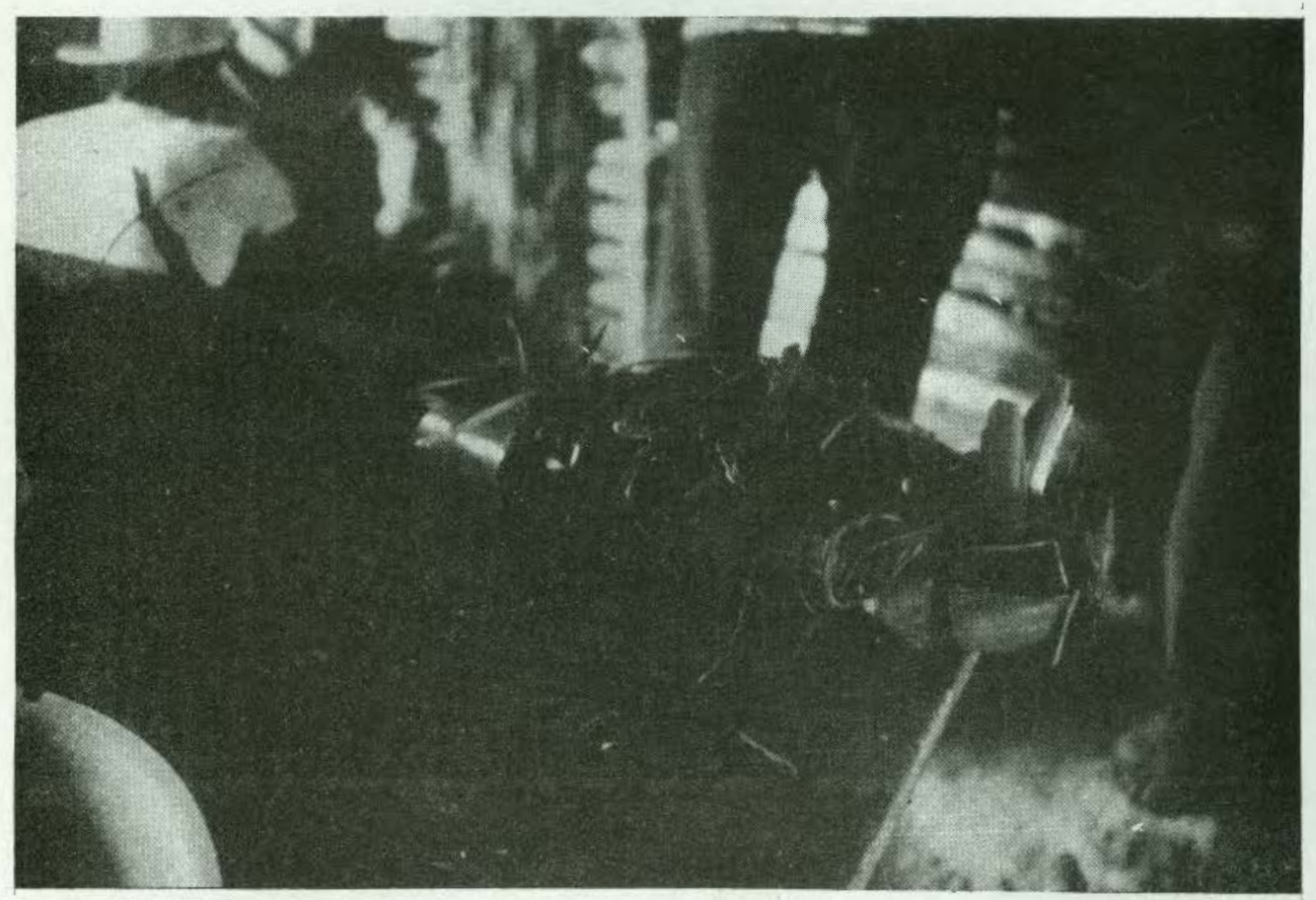

The wech, armadillo, to be baked with the breads.

Estudios de Cultura Maya. Vol. XV, 1984

Instituto de Investigaciones Filológicas/

Centro de Estudios Mayas, UNAM 


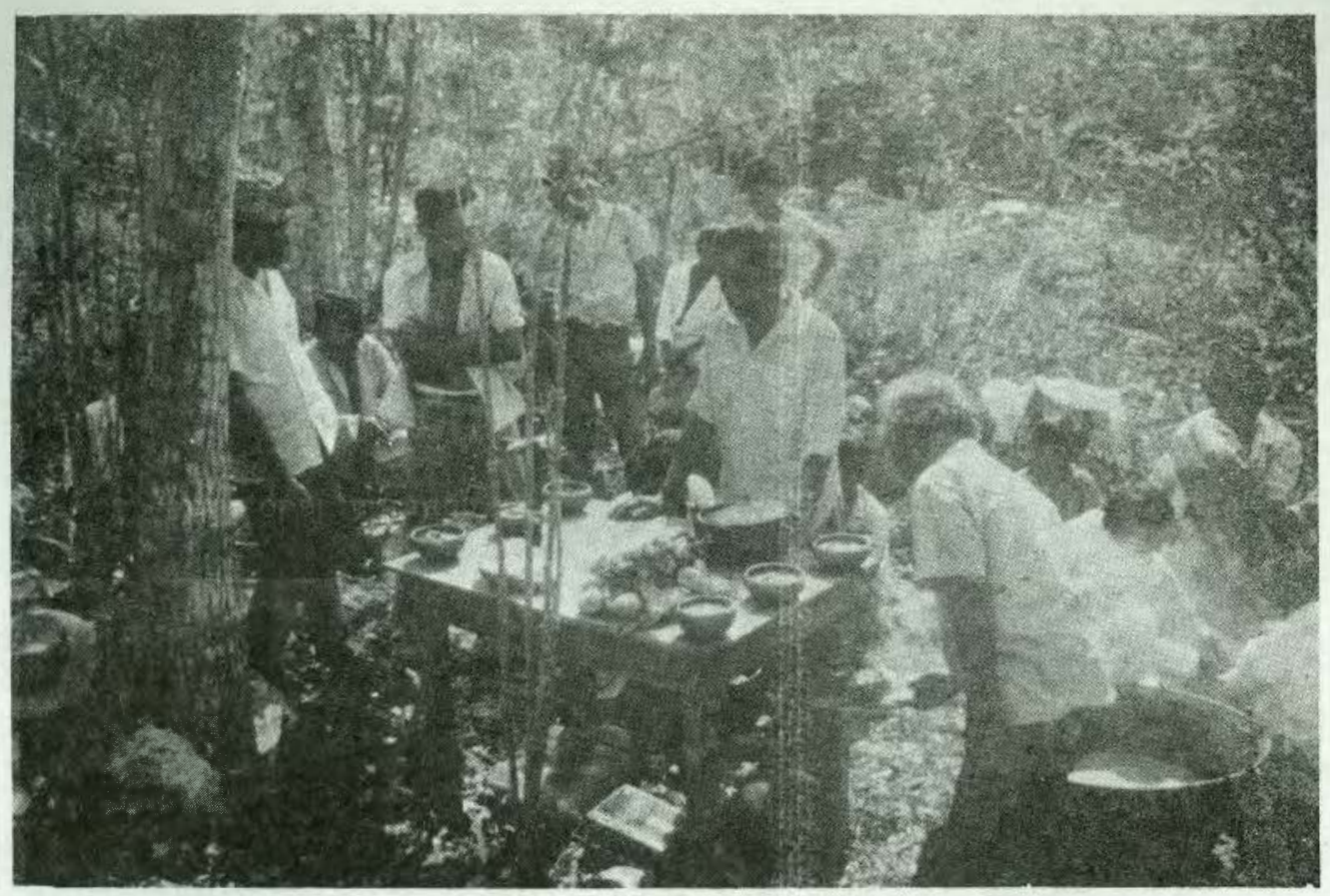

The third chant.

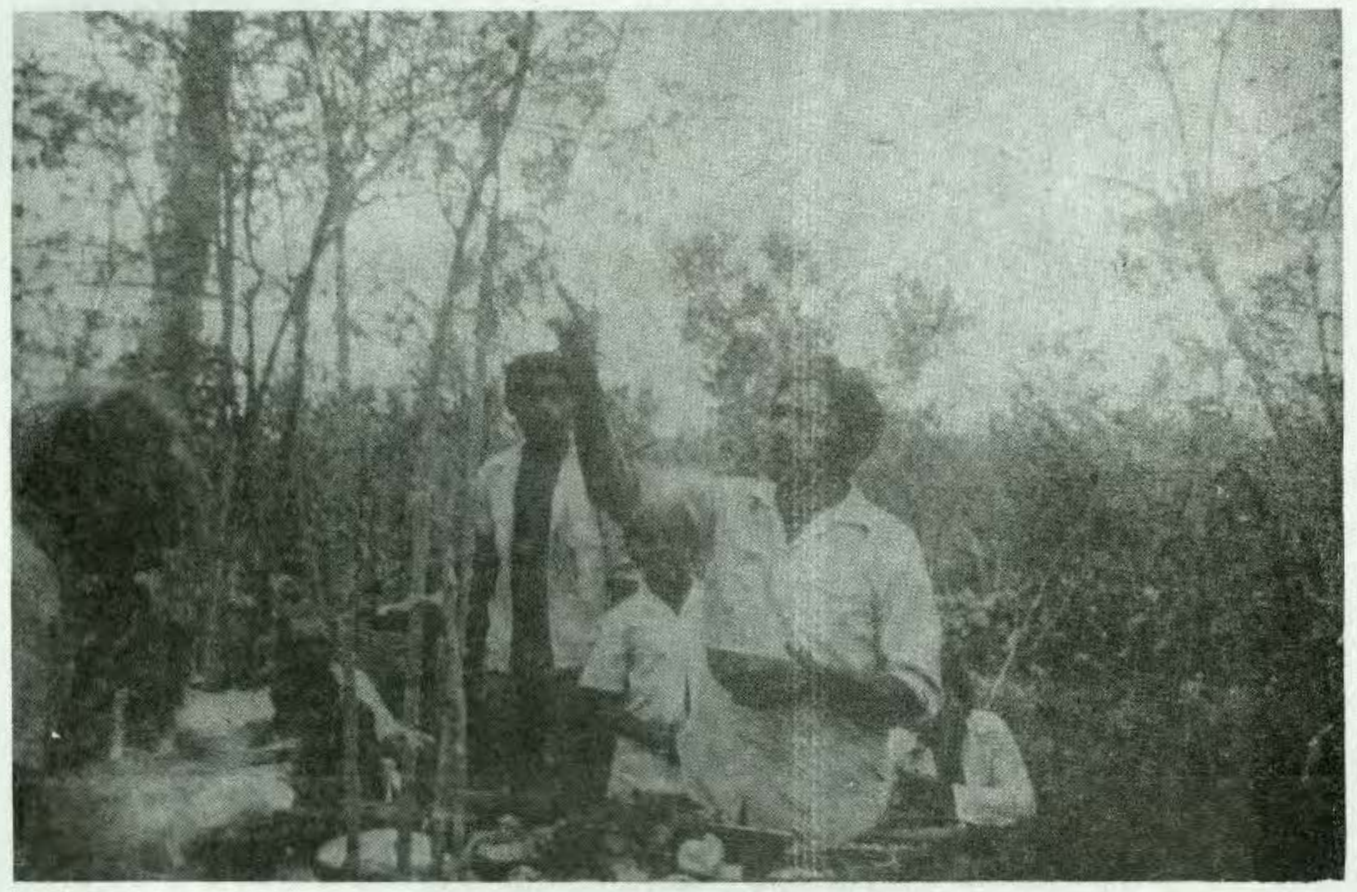

Sprinkling $k^{\prime} o l$ to the four world directions.

Estudios de Cultura Maya. Vol. XV, 1984

Instituto de Investigaciones Filológicas/

Centro de Estudios Mayas, UNAM 


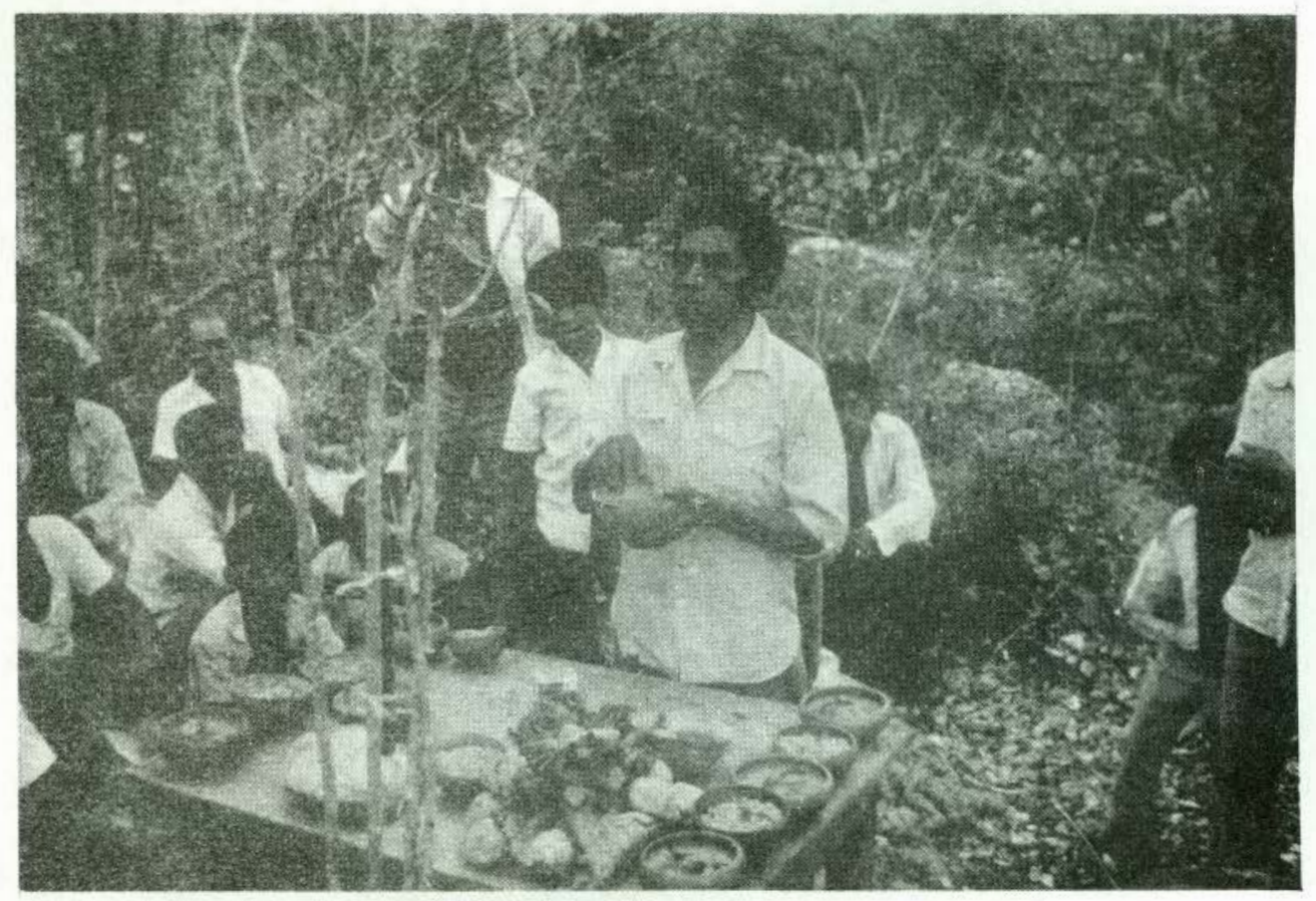

The fourth chant.

Estudios de Cultura Maya. Vol. XV, 1984

Instituto de Investigaciones Filológicas/

Centro de Estudios Mayas, UNAM

http://www.iifilologicas.unam.mx/estculmaya/ 